Historic, Archive Document

Do not assume content reflects current scientific knowledge, policies, or practices. 



\subsection{7}

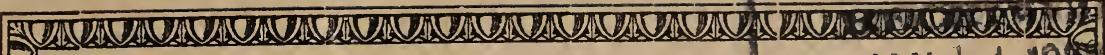

PRICE LIST FOR SPRING CORT2 $\star$ JAN 1419

- of -

THE LINN COUNTY i: 8

NURSERIES

SNYDER BROS., Inc.

Center Point, Iowa

ESTABIISHED 1895

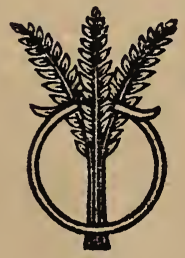

\section{GROWERS OF}

FVERGREENS

ORNAMIENTAI TREES AND PLANTS

FRUTT TREES

NUT TREES 


\section{TERMS AND DIRECTIONS}

LOCATION. Our nurseries are located just south of the C., R. I. \& P. and W., C. F. \& N. Stations in Center Point, eighteen miles from Cedar Rapids and twenty-five from Independence on Primary Road No. 11 (gravelled).

PACKING FACILITIES. These consist of a cellar and clay block building 100 feet square. Boxes and bales are well papered and the roots protected with moist packing. Evergreens and large trees are dug only as they are sent out.

PRICES given are for the stock, properly packed and delivered at the Nursery, the stations here, or at nearby towns in case we are making a general delivery there. Small plants will be sent by parcel post within the second zone or the third zone if not too heavy.

CONDITIONS. All orders are accepted on condition that they shall be void should any injury befall the stock from hail, frost, fire, or other causes beyond our control. Deliveries are subject to delay by bad weather, bad roads, strikes, accidents, embargoes and causes beyond our control.

TERMS are cash on or before the delivery of the stock, unless previously otherwise agreed upon.

CLAIMS for errors or shortage must be made immediately upon the receipt of the stock.

VISITORS WELCOME. At all seasons during business hours, visitors are welcome to inspect the grounds. Through the packing and shipping season time is not always available to show them about, but we are glad to do so when possible. Those wanting to select specimen trees can do so during the growing season and they will be marked for delivery at the proper time. Large trees to be moved with a frozen ball of earth should be selected before hard freezing so they can be mulched and thus save expense in digging.

MISCELLANEOUS. Supplies not everywhere obtainable, such as garden stakes, aluminum sulfate, imported peat, etc., are usually in stock and can bo supplied customers. Also numerous plants not in the list are being grown under trial and can be furnished. 


\section{APPLES}

Apple trees should be planted 30x30 feet apart. They respond to good cultivation and care as freely as does corn or any other crop. Our trees are graded according to the standard rules of grading. The 5 to 6 foot size ealiper $\frac{11}{16}$ in. and up; the other sizes $5 / 8$ to $\frac{11}{16}$ in. and $1 / 2$ to $5 / 8$ in., respectively. Many varieties will run considerably taller than rated, and a few dwarf growing kinds are shorter.

The following is a list of the main varieties of apples we have this spring, arranged approximately in the order of their ripening:

\section{EARLY VARIETIES}

\section{Liveland (Lowland Raspberry) Yellow Transparent \\ Duchess (Oldenburg) \\ Benoni}

Liveland is the best real early apple; it is beautifully colored, has the highest quality, and keeps remarkably for an early apple.

\section{FALL VARIETIES}

Nichner (Strawberry)

University

Bailey Sweet

Chenango
Ramsdell Sweet

Anism

Wealthy
Snow (Fameuse)
Wolf River
Longfield

Wealthy

Wolf River

Longfield

Nichner has been very profitable for years; it is very hardy, has good size and fair color, very fine grained white flesh of high quality, and ripens just after Duchess.

\section{WINTER VARIETIES}

\section{MeIntosh}

Sharon

Delicious

Jonathan

Ames

Grimes (Golden)

King David

Banana (Winter)

Golden Russet

Isherwood

Rome Beauty

Virginia Beauty
Greenville
Windsor
Iowa Blush
Hawkeye Greening
Tolman Sweet
Colorado Orange
Northern Spy
Roman Stem
N. W. Greening
Stayman (Winesap)

\author{
Allen's Choice \\ Salome \\ Mammoth Black Twig \\ York Imperial \\ Gano \\ Black Ben Davis \\ Willow Twig \\ Ben Davis \\ Nelson Sweet \\ Malinda \\ Rall's (Janet or Geniton)
}

MeIntosh we consider perhaps the most choice commercial variety for the north.

Windsor has been a very profitable variety with us. It is very hardly, a regular and heavy producer and is well colored, large, good, and late keeping. Some places it is subject to blight, but has not been here.

\section{CRAB APPLES}

Hyslop

Whitney (No. 20)

Virginia

White Arctic
Transcendant
Sweet Russet

Martha

Wild Red

Wynema

Wynema and Wild Red are hybrid Wild Crabs, with fruit about the size and color of Whitney, but otherwise like the small green wild crabs.

Virginia is unexcelled as a stock upon which to topwork varieties such as Jonathan, Grimes, Stayman, Mammoth Black Twig, Virginia Beauty, etc.

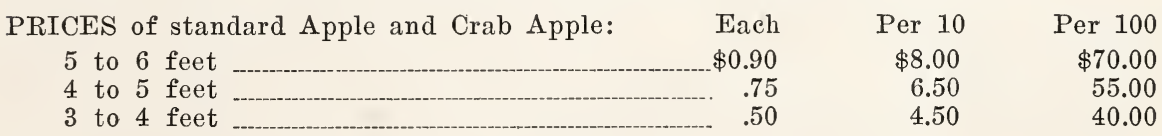




\section{DWARF APPLES}

Delicious

Wealthy

Yellow Transparent

PRICES of Dwarf Apple:

Each

Per 10

4 to 5 feet $\$ 1.00$

$\$ 9.00$

\section{ANOKA}

Anoka, The Wonder Apple, of Prof. Hansen, is not strictly a dwarf but a hybrid which bears extremely young. He says, "The fruit is two and one-half inches in diameter, round, Duchess type of coloring, flesh white, good subacid, season September."

PRICE of Anoka:

Each

Per 10

5 to 6 feet $\$ 1.00$

$\$ 9.00$

\section{PEACHES}

Peaches in central Iowa should be planted where they will have as much protection as possible.

Leading varieties-Champion, Bokara, and Elberta.

PRICES-

Budded trees

4 to $5 \mathrm{ft}$.

Each

$\$ 0.60$

.45

Per 10

$\$ 5.00$

4.00

\section{PEARS}

More than one variety should be planted to insure pollination. The standard, or large growing trees, should be spaced 18 to $20 \mathrm{ft}$. apart; the Dwarfs, $10 \mathrm{ft}$. The following is a list of the varieties we have, arranged in approximate order of ripening:

\section{Wilder}

Clapp's Favorite

Longworth

Isincoln

PRICES of all Standard Pears:

\section{Bartlett}

Seckel

5 to 6 feet

4 to 5 feet

3 to 4 feet

Flemish Beauty

Kieffer

Patten (4-5 ft. size only)

Anjou

DWARF PEARS are grafted on Quince roots, which dwarf and bring them into bearing earlier. The following varieties in the 4 to 5 and 3 to 4 foot sizes only:

Clapp's Favorite

Duchess
Bartlett

Seckel

Flemish Beauty
Kieffer

Anjou

PRICES of all Dwarf Pears:

Each

4 to 5 feet

3 to 4 feet

Duchess does particularly well as a dwarf. 


\section{CHERRIES \\ (In order of ripening)}

Dyehouse

Early Richmond

\author{
Montmorency \\ Ostheime \\ Yellow Glass
}

\author{
Wragg \\ English Morello
}

Early Richmond and Montmoreney are the most dependable and the most planted. Yellow Glass is a true, sweet cherry and is more tender than the others. Wragg and English Morello are very late and very dark in color.

PRICES of above varieties except Yellow Glass-

Each Per 10

These are the same grades used other years. The caliper governs. Bushy varieties often are shorter than rated.

$\frac{11}{16}$ in.
$\frac{9}{16}-\frac{11}{16}$ in.
$\frac{7}{16}-\frac{9}{16} \mathrm{in}$.

mostly 5-6 ft. mostly 4-5 ft. mostly $3-4 \mathrm{ft}$.
$\$ 1.00$

$\$ 9.00$

.90

8.00

.70

\section{PLUIMS}

Abundance
Beatty
Bohemian Prune
Burbank
Compass
Communia
Damson
Desoto
Fellenburg

Beatty

Bohemian Prune

Burbank

Compass

Communia

Desoto

Fellenburg
Abundance

German Prune
Gold
Hanska
Hennepin
Lombard
Mary
Miner
Mrs. Cleveland
Omaha
Opata

German Prune

Gold

Ianska

Mary

Miner

Omaha

Opata

Red Wing
Sapa
Surprise
Terry
Toka
Underwood
Wachampa
Winona
Wyckoff

Terry, Beatty, and Desoto are all pure American varieties of splendid quality for all purposes, and we believe most dependable of all for the far North.

Red Wing, Hennepin, Underwood, and Winona are a new group of plums which recently originated at the Minnesota State Fruit Breeding Farm. They are all large or very large and excellent varieties. Red Wing has done extra well here.

Abundance and Burbank are Japanese varieties, which are much prized by some, but usually overbear and are short-lived here.

Sapa, Opata, and Wachampa are all hybrids of the Western Sand Cherry produced by Professor Hansen, and all make very erooked trees. Sapa is of medium size, has purplish flesh, a very small pit, and is very fine for eanning. Wachampa is very similar to Sapa except the flesh is a lighter color. Opata has green flesh and is very early, but not especially good for cooking.

Hanska and Toka are also hybrids produced by Professor Hansen and generally included in the group known as the Harisen Hybrids. They are crosses of the Ameriean Plum and Prunus Simoni. Both varieties are very straight, symmetrical, upright trees. The fruit is bright red, of good size, and has a very pronounced apricot fragrance and flavor. Many people think them the best plums in our whole list.

Communia, Damson, German Prune, Pacific Prune, and Lombard are all European varieties, which are often spoken of as blue plums.

Bohemian Prune is one of the hardiest European varieties and a splendid prune.

Wyckoff is a variety of medium size and light red color with a very thin skin and especially fine for canning, no other varietey excelling it for this purpose.

Mary and Rheine Claude are European plums belonging to the Green Gage type. Mary has proved very productive and the plums are perhaps the sweetest of any variety we have. They are a clear green color, which they hold in canning.

PRICES of Plum Trees:

5 to 6 feet

Each $\$ 1.00$

4 to 5 feet .80

Per 10

3 to 4 feet 


\section{GRAPES \\ (In order of ripening)}

Beta, black

Hungarian, black

Moore Early, black

Diamond (Moore's), white

Wyoming, red
Elvira, white

Worden, black

Delaware, red

Lucile, red

Niagara, white
Caco, red

Lutie, red

Concord, black

Woodruff, red

Agawan, red

Beta, Hungarian and Elvira are small grapes, but very hardy and well suited for arbors and pergolas.

Coneord is the best shipping variety and predominates in commercial plantings.

Worden and Moore Early are larger and sweeter than Concord and should be included in the home vineyard.

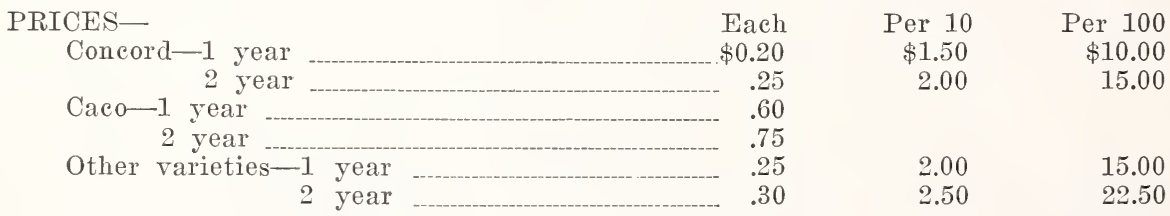

\section{CURRANTS} Iowa.

Currants cannot be sent across the quarantine line, which is the western line of

Victoria

Wilder

2-year Bushes-

Perfection

Other varieties
White Grape

Cherry

Perfection
Diploma

Fay (Fay's Prolific)

$\begin{array}{rrr}\text { Each } & \text { Per } 10 & \text { Per } 100 \\ \$ 0.40 & \$ 3.50 & \$ 30.00 \\ -.30 & 2.50 & 17.50\end{array}$

\section{GOOSEBERRIES}

Subject to the same quarantine as Currants.

Champion

PRICES-2-year plants
Downing

Pearl
Carrie

$30 \mathrm{e}$ each
$\$ 2.50$ per 10

\section{JUNEBERRIES (Serviceberry, Shadbush)}

Juneberry bushes are highly ornamental at all seasons of the year as well as being valuable for their fruit, which is much liked by the birds and attracts them from other berries and the cherries. Planted in a hedge row, they make an oval hedge 6 to 8 feet high and about that width.

$\begin{array}{rrr}\text { PRICES-For transplants- } & \text { Each } & \text { Per } 10 \\ 12 \text { to } 18 \text { inch bushes } & \$ 0.20 & \$ 1.50 \\ 18 \text { to } 24 \text { inch bushes } & .25 & 2.00 \\ 2 \text { to } 3 \text { foot bushes } & .35 & 3.00 \\ 3 \text { to } 4 \text { foot bushes } & \end{array}$




\section{RASPBERRIES}

The purple and black varieties grow from tips, red ones from suckers. For home use the purple caps will produce more fruit than the others.

Cumberland is the most planted of the black caps.

Latham is far the best and most profitable of the red varieties. Plant in hedge rows about two feet apart in the rows.

Cardinal, purple

Cumberland, black

St. Regis, red everbearing

PRICES-

Purple varieties and Latham.

Other varieties
Haymaker, purple

Royal Purple, purple

King, red
Louden, red

Latham, red

\section{BLACKBERRIFS AND DEWBERRIES}

We have found the Snyder Blackberry the most dependable of many kinds tried and confine our growing to it. All the plants offered are root eutting plants; none are suckers from an old run-out patch.

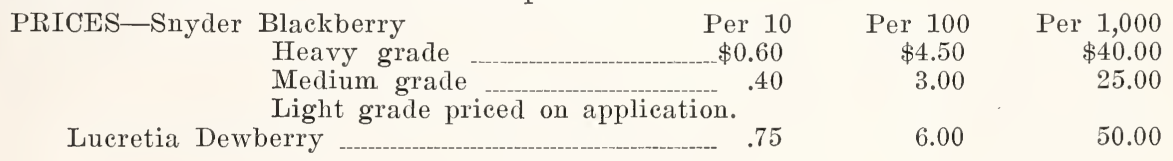

\section{STRAWBERRIES}

The Dunlap Strawberry suceeds so well under so many different conditions and is so good for all purposes that we advise it as the best spring bearing variety for general planting. Put out a new bed each year in rows $3 \frac{1}{2}$ to 4 feet apart and 18 inches in the row.

The fall bearing Strawberries do best north of central Iowa, where if proper eare is given and conditions are favorable, wonderful results are often obtained. They should be planted early in the spring on good, rich ground and a new pateh planted each year.

$\begin{array}{lrr}\text { PRICES- } & \text { Per } 100 & \text { Per } 1,000 \\ \text { Dunlap } & \$ 1.00 & \$ 9.00 \\ \text { Progressive, fall bearing } & 2.50 & 20.00 \\ \text { Champion, fall bearing } & & 20.00\end{array}$

\section{ASPARAGUS}

This is one of the first ready to use and most wholesome of the spring vegetables. Plant it along the fence and plant it by the hundred rather than by the dozen.

Martha Washington (Rust Proof), or the older varieties.

$\begin{array}{ccrr}\text { PRICES- } & \text { Per } 10 & \text { Per } 100 & \text { Per } 1,000 \\ \text { Two-year plants } & \$ 0.40 & \$ 2.50 & \$ 20.00\end{array}$

\section{RHUBARB}

Rhubarb, like Arsparagus, should be planted where it need not be disturbed and will produce a great lot of wholesome food with the minimum amount of work. Heavy clumps of it may be foreed in the cellar in winter if they are dug in the fall and allowed to freeze hard before taking in.

$\begin{array}{lrrr}\text { PRICES- } & \text { Each } & \text { Per } 10 & \text { Per } 100 \\ \text { Two-year roots } & \$ 0.20 & \$ 1.50 & \$ 10.00 \\ \text { One-year roots } & .15 & 1.00 & 6.00\end{array}$




\section{EVERGREENS}

All the evergreens we offer have been transplanted two or more times unless otherwise noted. They are always dug fresh as sent out. If the buyer comes to the Nursery after them, they can be lifted directly from the row to his truck and have a minimum of exposure. If the roots of evergreens ever become thoroughly dry they cannot be revived as other trees can. Failure in transplanting them is largely due to allowing them to become dry while planting, to not packing good, mellow, moist soil very firmly around the roots, or to not properly conserving moisture about them through the summer by frequent shallow eultivation and by mulching.

SPACING. Plant Pines or Spruces 7 to 8 feet apart for single row windbreaks, and 10 to 12 feet apart for double rows. For low hedges plant 18 to 24 inches apart, depending on size.

SoILs. Plant Pines on dry or well drained soil. The Bull Pine will do well on very gravelly soil. In places where it is quite wet at times Spruce will be better, and in very wet places Arborvitae is the best.

PESTS. Red Spider or Mite has caused much trouble during a droutin in the growing season. A rusty appearance is likely to be due to it. Water applied under a high pressure to the tops every few days is an effective remedy, or a soluble oil spray applied according to the manufacturer's directions is also effective.

\section{EVERGREENS FOR WINDBREAKS AND HEDGES}

Prices in this section do not include Ball and Burlap; if wanted that way, the expense of it must be added. Each $\mathrm{X}$ represents one transplanting.

ARBORVITAE-American, Thuja occidentalis

A native of the north, preferring a moist soil and enduring partial shade.

PINE-Bull, Pinus ponderosa, Western Yellow Pine

A native of the Black Hills, with very long needles and thick, stout branches, which are not broken by heavy sleet or severe storms. Extremely hardy and drouth-resistant.

\section{PINE-White, Pinus strobus}

One of Iowa's few native conifers and one of the best for windbreaks.

RED CEDAR - Juniperus virginiana Should not be planted near apple trees because of the Cedar Apple rust, otherwise very desirable.
Size

$8-12$ in. $\mathrm{X}$

$12-15$ in. $\mathrm{XX}$

$15-18$ in. $\mathrm{XX}$

$18-24$ in. $\mathrm{XX}$

18-24 in. $\mathrm{XX}$

$2-3 \mathrm{ft} . \mathrm{XX}$

3-4 ft. XXX

4-5 ft. XXX

5-6 ft. XXX
Each Per 10

$\$ 0.25$

.45

.60

.75

.50

.60

.70

.85

1.00

12-15 in. $\mathrm{XX}$

15-18 in. $\mathrm{XX}$

18-24 in. XX

2-3 ft. XX

18-24 in. $\mathrm{XX}$

2-3 ft. XX

12-15 in. $\mathrm{XX}$

15-18 in. XX

18-24 in. XX

$2-3 \mathrm{ft}$. XX
Per 100

$\$ 2.00$

4.00

5.50

7.00

$\$ 17.50$

35.09

50.00

65.00

4.50

40.00

5.00

45.00

6.00

55.00

8.00

9.50

75.00

90.00

\subsection{0}

4.50

5.50

7.00

30.00

40.00

50.00

60.00

\section{SPRUCE-Norway, Picea excelsa}

Native to Northern Europe. Most grown and recommended by Nurserymen because it is the easiest to grow.

2- $\mathrm{XX}$ 


\section{SPECIMEN EVERGREENS--For Landscape Planting}

(Prices in this section include ball and burlap)

The following are well developed trees which have been several times transplanted and are dug with a solid ball of earth securely burlapped and bound. They are much heavier to handle, but easier to plant and more certain to grow. In planting do not remove the burlap. After the tree is in place and hole partly filled to hold it, cut the burlap loose around the top and pour in plenty of water. Large trees over 8 feet should be ordered before hard freezing so they can be mulched for digging and the ball of dirt frozen solidly before moving. Imperfect specimens (defective on one side or at the bottom) can often be used as effectively in groups and will be priced according to quality. Each $\mathrm{X}$ represents one transplanting.

Size

Each

ARBORVITAE-American

18-24 in. $\mathrm{XXX}$

$\$ 1.50$

Sheared Trees.

$2-3$ ft. XXX

2.00

3-4 ft. XXX

2.50

4-5 ft. XXX

3.00

5-6 ft. XXX

4.00

Globe

10-12 in. XX

A dwarf form which makes compact globes with-

$12-15$ in. $\mathrm{XX}$

1.50

out trimming.

$15-18$ in. $\mathrm{XX}$

2.00

$18-24$ in. $\mathrm{XX}$

2.50

Geo. Peabody's Golden

$15-18$ in. $\mathrm{XXX}$

A clear golden yellow on the tips, needs shearing 18-24 in. XXX

to make it compact.

Pyramidal

9-12 in. XXX

Grows in columnar form without shearing.

12-15 in. XXX

$15-18$ in. $\mathrm{XXX}$

2.50

18-24 in. XXX

$2-21 / 2$ ft. XXX

21/2-3 ft. XXX

Siberian

12-15 in. $\mathrm{XX}$

$15-18$ in. $\mathrm{XXX}$

1.50

2.00

The hardiest of all the Arborvitae, very compact,

18-24 in. XXX

2.50

foliage.

$2-2 \frac{1}{2}$ ft. XXX

FIR-Balsam

$3-4$ ft. $\mathrm{XXX}$

A native of Iowa and Northeast. It should have

4-5 ft. XXX

3.50 moist soil. The leaves and branches are delight-

$5.6 \mathrm{ft} . \mathrm{XXX}$

4.00

fully fragrant.

Concolor

18-24 in. $\mathrm{XXX}$

Larger sizes quoted on application.

$2-21 / 2$ ft. $X X X$

Douglas-Also known as Douglas Spruce 


\section{SPECIMEN EVERGREENS-Continued}

Size

Each

JUNIPER—Pfitzer's

$12-15$ in. $X X$

2.00

A rariety of the Chinese Juniper. The foliage is bluish green and the branches grow out horizontally from the stem, which gives the tree an individuality of its own. Sizes apply to width rather than height.

$15-18$ in. $\mathrm{XXX}$

$18-24$ in. XXX

$2-21 / 2$ ft. $X X X$

$21 / 2-3$ ft. XXX

3.00

4.00

5.00

6.00

J. cracovica

$12-15$ in. $\mathrm{XX}$

An upright, many-branched variety with sil- 15-18 in. XX

very green foliage.

J. Horizontalis glauca

15-18 in. $\mathrm{XX}$

A very low ground-covering type with $2-21 / 2 \mathrm{ft}$. XX

thread-like steel blue foliage. Rapid grow-

ing, dense, and very fine.

J. sabina tamariscifolia

$12-15$ in. $\mathrm{XX}$

A vigorous low-growing variety about $1 \mathrm{ft} . \quad 15-18$ in. XX

high and wide-spreading with bluish graygreen foliage.

Savin

A bushy little tree with semi-erect branches and clear green foliage. It is excellent for foundation plantings and in rockeries or dry sunny places.

Virginian, Red Cedar

$9-12$ in. $\mathrm{XX}$

$12-15$ in. XX

15-18 in. XX

18-24 in. XX

18-24 in. $\mathrm{XX}$

2-3 ft. $X X$

3-4 ft. $\mathrm{XX}$

4-5 ft. XXX

5-6 ft. XXX

6-7 ft. XXX

18-24 in. XX

2-3 ft. XX

3-4 ft. XX

6-7 ft. XX

3-4 ft. XXX

4-5 ft. XXX

5-6 ft. XXX

6-7 ft. XXX

9-12 in. $X X$

$12-15$ in. $X X$

$2-21 / 2$ ft. $X X X$

$21 / 2-3$ ft. XXX

6-7 ft. XXX

3-4 ft. XXX

6-7 ft. XXX

1.50

2.50

3.00

4.00

1.50

2.00

3.00

4.50

6.00

7.50

1.00

1.50

2.50

5.00

2.50

3.50

4.50

6.00

1.50

2.00

6.00

7.50

5.00

A native of northern Wisconsin. Needles long and soft and a very pretty green. One of the most beautiful pines.

\section{Scotch}

Bright green at all times and endures city conditions exceptionally well. May be sheared into any form. 


\section{SPECIMEN EVERGREENS-Continued}

\begin{tabular}{|c|c|c|}
\hline & Size & Each \\
\hline White & $2-3$ ft. $\mathrm{XX}$ & 2.50 \\
\hline $\begin{array}{l}\text { The softest foliage of the pines. Endures some } \\
\text { shade and is the longest-lived pine here. }\end{array}$ & 6-7 ft. XXX & 6.00 \\
\hline RUCE-Black Hills & $12-15$ in. $\mathrm{XXX}$ & 1.25 \\
\hline A native of the Black Hills. It does very well & $15-18$ in. $\mathrm{XXX}$ & 1.50 \\
\hline over a wide range and makes the finest specimens & $18-24$ in. $\mathrm{XXX}$ & 2.00 \\
\hline of all Spruce. This is a very variable species, & $2-21 / 2$ ft. XXX & 2.50 \\
\hline ranging from very compact dwarfs to more open, & $21 / 2-3$ ft. XXX & 3.00 \\
\hline rapid-growing trees, and from clear green to sil- & $3-4$ ft. $\mathrm{XXX}$ & 4.00 \\
\hline very blue-green. & $4-5 \mathrm{ft}$. & 5. \\
\hline & $5-6 \mathrm{ft} . \mathrm{XXX}$ & 6.50 \\
\hline & $\mathrm{XXX}$ & 8.00 \\
\hline
\end{tabular}

\section{Colorado Blue}

A native of Colorado. It varies from clear green to glistening silvery blue. They are slowgrowing and very compact, making the finest lawn specimens.

Selected Blue Specimens or Shiners

18-24 in. $\mathrm{XXX}$

\section{Green Specimens}

These often, but not always, develop a blue color with age.

$2-21 / 2$ ft. $X X X$

21/2-3 ft. XXX

3-4 ft. XXX

$4-5 \mathrm{ft}$. XXX

5-6 ft. XXX

Norway

White, American White Spruce

Resembles Black Hills Spruce, though less compact and more rapid-growing.

YEW-Taxus canadensis, Canada Yew

Requires shade.

Taxus cuspidata brevifolia, Japanese Yew Prefers some shade.
2-3 ft. XXX

3-4 ft. XXX

2-3 ft. XXX

3-4 ft. XXX

4-5 ft. XXX

5-6 ft. XXX

6-7 ft. XXX

9-12 in. XX 12-15 in. XX

6-9 in. $\mathrm{XX}$ 9-12 in. XX
3.00

3.50

4.50

6.00

8.00

2.50

3.00

2.00

3.00

4.00

5.00

6.50

1.00

1.50

1.00

1.50 


\section{DECIDUOUS TREES AND SHRUBS}

This year we are listing these under one heading, as it is difficult to distinguish between trees and shrubs and there is no reason for trying to do so. Preference is given the botanical names except where common names are well established and better known. We can furnish much larger specimens of many of these trees and shrubs where they can be delivered by truck, and invite correspondence regarding any such sizes which may be wanted. If larger quantities are wanted than are quoted, ask for prices. The sizes given with the description are the average size at maturity.

$\begin{array}{lrrr} & \text { Size } & \text { Each } & \text { Per } 10 \\ \text { ACANTHOPANAX pentaphyllum } & 2 \text { to } 3 \mathrm{ft} . & \$ 0.50 & \$ 4.00 \\ \text { Shrub, } 6 \text { to } 8 \mathrm{ft} \text {. Spiny. } & 3 \text { to } 4 \mathrm{ft} & .60 & 5.00 \\ \text { AILANTHUS, Tree of Heaven } & 3 \text { to } 4 \mathrm{ft} & .90 & 8.00 \\ \text { Medium, not fully heardy north. } & 4 \text { to } 5 \mathrm{ft} . & 1.25 & 10.00\end{array}$

ALMONDS-Flowering See Prunus Glandulosa.

ALTHEAS, Rose of Sharon 2 to $3 \mathrm{ft}$.

Shrub, 10 to $12 \mathrm{ft}$. where hardy. Vari- 3 to $4 \mathrm{ft}$.

ous colors.

AMELANCHIER. See Juneberries, Page 4.

AP.ONIA arbutifolia, Red Chokeberry _.... 12 to 18 in.

Shrub, 6 to $10 \mathrm{ft}$. Red berries in fall. 18 to $24 \mathrm{in}$.

Melancarpa, Black Chokeberry

Shrub, 4 to $6 \mathrm{ft}$. Black fruit in

early fall.

ASH-American

2 to $3 \mathrm{ft}$.

1.00

1.50

2.00

BARBERRY, Japanese

7 to $8 \mathrm{ft}$.

8 to $10 \mathrm{ft}$.

See under Hedge Plants.

BIRCH-European White 5 to $6 \mathrm{ft}$.

Medium, plant only in early spring. 6 to $8 \mathrm{ft}$.

BLADDERNUT, Staphylea Trifolia 18 to $24 \mathrm{in.}$

Shrub, 8 to $10 \mathrm{ft}$. Compound leaves.

Green striped branches.

BUTTERFLY BUSH, Buddleia strong 2-year

Shrub, 3 to $8 \mathrm{ft}$. Spikes of rose colored flowers with orange eye, from

strong 1-year

July on.

\section{BUTTON BUSH, Cephalanthus}

occidentalis 18 to $24 \mathrm{in}$

Dense shrub, 4 to $6 \mathrm{ft}$. Flowers in 4 to $5 \mathrm{ft}$.

round balls, greenish white, in July.

CARAGANA, Siberian Pea Tree 18 to $24 \mathrm{in}$.

Small tree, to $20 \mathrm{ft}$. Soft pea green foliage, very early, and bright yellow

2 to $3 \mathrm{ft}$. flowers.

CATALPA-Speciosa, Western Catalpa Large. Flowers abundantly in June.

Bungei-Grafted heads Flatly globular tops.
3 to $4 \mathrm{ft}$.

5 to $6 \mathrm{ft}$. whips

6 to $8 \mathrm{ft}$.

$51 / 2$ to $6 \mathrm{ft}$. stems

5 to $5 \frac{1}{2} \mathrm{ft}$. stems
.50

.75

1.00

4.00

6.00

9.00

10.00

14.00

18.00

16.00

22.00

.50

.00
.00

4.00

9.00

.50
1.00

2.00

3.00

4.00

.40

.50

6.50

.75

10.00

3.00

25.00

2.50

20.00 


\section{DECIDUOUS TREES AND SHRUBS--Continued}

Size Each

Per 10

CLETHRA Alnifolia, summersweet 12 to $18 \mathrm{in.}$ Shrub, 3 to $5 \mathrm{ft}$. Fragrant ereamy- 18 to 24 in. .50 white flowers in upright racemes in August-September.

CORALBERRY, Indian Currant,

Symphoricarpos vulgaris 12 to 18 in.

Shrub, 2 to $5 \mathrm{ft}$. Endures dense shade. 18 to 24 in.

Covered with red berries in early 2 to $3 \mathrm{ft}$.

winter.

\section{CORNUS, Dogwood}

alternifolia, Pagoda Dogwood 18 to $24 \mathrm{in.}$

Shrub to $20 \mathrm{ft}$. Horizontal branches,

2 to $3 \mathrm{ft}$. red twigs, blue berries.

elegantissima or variegated leaved

\section{florida}

Small tree, $3-3 \frac{1}{2}$ inch white flowers before the leaves. Fall foliage colors beautifully. Fruit bright red.

alba siberica, red twigged Shrub, 8 to $10 \mathrm{ft}$. Branches blood red.

18 to $24 \mathrm{in}$.

2 to $3 \mathrm{ft}$.

3 to $4 \mathrm{ft}$.

18 to $24 \mathrm{in}$.

2 to $3 \mathrm{ft}$.

3 to $4 \mathrm{ft}$.

stolonifera lutea, yellow twigged Shrub, 6 to $8 \mathrm{ft}$. Golden yellow branches.

12 to 18 in.

18 to $24 \mathrm{in.}$

2 to $3 \mathrm{ft}$.

mas, Cornelian Cherry

Small tree with yellow flowers be-

18 to 24 in.

2 to $3 \mathrm{ft}$.

fore the leaves. Red fruit attrac-

tive to the birds.

COTONEASTER, Acutifolia, Peking

CRABS-All small growing trees, flowering in May.

Bechtel's Double Flowering

Double rose pink fragrant flowers.

Single brilliant carmine flowers.

Hoppa, Hansen's Red Siberian More rapid growing kind with red flowers, fruit, new growth, and wood. Similar to the old Red Vein variety and we believe will displace it.
18 to $24 \mathrm{in}$.

2 to $3 \mathrm{ft}$.

3 to $4 \mathrm{ft}$.

4 to $5 \mathrm{ft}$.

5 to $6 \mathrm{ft}$.

18 to $24 \mathrm{in}$.

2 to $3 \mathrm{ft}$.

3 to $4 \mathrm{ft}$.

3 to $4 \mathrm{ft}$.

4 to $5 \mathrm{ft}$.

5 to $6 \mathrm{ft}$.
1.50

2.00

2.50
9.00

12.00

18.00

22.50

6.00

9.00

12.00

10.00

12.50

15.00 


\section{DECIDUOUS TREES AND SHRUBS--Continued}

$\begin{array}{llr} & \text { Size } & \text { Each } \\ \text { Parkman } & 3 \text { to } 4 \mathrm{ft} . & 1.50 \\ \text { Double bright rose red on slender } & 4 \text { to } 5 \mathrm{ft} . & 2.00 \\ \text { stems. } & \end{array}$

Each

Per 10

1.50

12.50

Double

.00

18.00

CRANBERRY, Highbush, Viburnum

\section{opulis}

12 to 18 in.

.60

.75

Shrub, 6 to $10 \mathrm{ft}$. Bright scarlet fall 18 to $24 \mathrm{in}$.

1.00

5.00

fruit.

2 to $3 \mathrm{ft}$.

7.00

9.00

CURRANTS, Ribes

Odoratum, fragrant yellow flowers _-_- 2 to $3 \mathrm{ft}$. Very early. Shrub, 4 to $6 \mathrm{ft}$.

Alpine, Mountain Currant

12 to 15 in.

Dwarf, e o m p a t, shade-enduring 15 to 18 in. plant.

DESMODIUM pendulifolium 2-year No. 1

Half shrub, 3 to $5 \mathrm{ft}$. Drooping racemes, Magenta purple flowers late summer.

DEUTZIA crenata

Shrub, 3 to $6 \mathrm{ft}$. Pinkish flowers.

Lemoine

Small shrub. Large, pure white

18 to $24 \mathrm{in}$.

flowers.

\section{ELDER, Sambucus}

Canadensis, Common American Elder 2 to $3 \mathrm{ft}$. 6 to $12 \mathrm{ft}$.

\section{3 to $4 \mathrm{ft}$.}

Cut Leaved

2 to $3 \mathrm{ft}$.

A variety with finely cut foliage.

3 to $4 \mathrm{ft}$.

Golden

Red Berried, pubens

18 to $24 \mathrm{in}$.

\section{Moline}

3 to $4 \mathrm{ft}$.

Tall, upright growing tree with very

large leaves thickly spaced. 


\section{DECIDUOUS TREES AND SHRUBS-Continued}

\section{EUONYMUS}

Size

Each

Per 10

alatus, Winged Wahoo 18 to 24 in.

Broad corky wings on twigs, red 2 to $3 \mathrm{ft}$.

berries, brilliant autumn foliage. A

6 to $8 \mathrm{ft}$.

atropurpurea, Burning Bush 12 to $18 \mathrm{in}$. A native shrub, 6 ot $12 \mathrm{ft}$. Copious 18 to $24 \mathrm{in.}$ crimson fruit in autumn.

radicans 15 to $18 \mathrm{in}$.

An evergreen shrubby vine for

planting in protected places.

FORSYTHIA intermedia, Yellow Bells 18 to 24 in.

Yellow flowers, very early. Shrub 2 to $3 \mathrm{ft}$.

6 to $8 \mathrm{ft}$.

has remained unchanged through the geological ages.

\section{HACKBERRY}

Large, strong, rapid growing, splen-

did shade tree.

5 to $6 \mathrm{ft}$.

\section{HONEYSUCKLE, Lonicera}

\section{Bella Albida}

\section{Morrow's} 18 to 24 in. Broad spreading bush, 6 to $8 \mathrm{ft}$., 2 to $3 \mathrm{ft}$. pinkish flower.

Tartarian, Pink or White 18 to 24 in. Upright shrub 6 to $8 \mathrm{ft}$. Pink or 2 to $3 \mathrm{ft}$. white flowers.

\section{HYDRANGEA}

Arborescens, Hills of Snow 12 to 18 in.

Paniculata grandiflora

Hardy Hydrangea.

Bush Form Shrub, 5 to $9 \mathrm{ft}$. Very large panicles turning reddish, then brown.

Tree Form 12 to 18 in.

18 to 24 in. 


\section{DECIDUOUS TREES AND SHRUBS-Continued}

\section{Size}

2 to $3 \mathrm{ft}$.

KENTUCKY COFFEE TREE

Medium. Large compound leares. 3 to $4 \mathrm{ft}$.

Short, thick, fleshy seed pods.
Each

1.00

1.25

\section{LILACS, Botanically Syringa}

Prefer a limestone soil.

Common Purple and Common White 18 to 24 in.

S. Japonica, Tree Lilac

3 to $4 \mathrm{ft}$. Small tree, rellowish white flowers 4 to $5 \mathrm{ft}$. in immense panicles, very late.

S. josikaea Upright shrub 12 to $15 \mathrm{ft}$. Dark glossy foliage and bluish purple flowers. Very late.

S. microphylla Arching shrub 6 to $8 \mathrm{ft}$. Pale lavender flowers in June and again in autumn.
18 to $24 \mathrm{in}$.

2 to $3 \mathrm{ft}$.

3 to $4 \mathrm{ft}$.

18 to $24 \mathrm{in}$.

2 to $3 \mathrm{ft}$.

18 to $24 \mathrm{in}$.

2 to $3 \mathrm{ft}$.

3 to $4 \mathrm{ft}$.

18 to $24 \mathrm{in.}$

2 to $3 \mathrm{ft}$.

3 to $4 \mathrm{ft}$.
.60

.75

1.00

1.50

2.00

14.00

18.00

5.00

7.00

9.00

foliage and pale lilac flowers.

Fine

.60

.75

1.00

5.00

7.00

9.00

.60

5.00

7.00

1.00

LILACS_Named Tarieties, "French

Lilaes",

Alphonse Lavalle 3 to $\pm \mathrm{ft}$.

Double. Violet-blue panicles.

Belle de Nancy 18 to $24 \mathrm{in}$.

Charles Tenth 18 to $24 \mathrm{in}$.

Dr. Von Regal

18 to 24 in.

Jean Bart

18 to 24 in.

Leon Ganbetta 18 to 24 in.

Louvain, Lovaniensis 18 to $24 \mathrm{in}$. Single, silvery pink.

Ludwig Spaeth Single, very dark purple. 


\section{DECIDUOUS TREES AND SHRUBS-Continued}

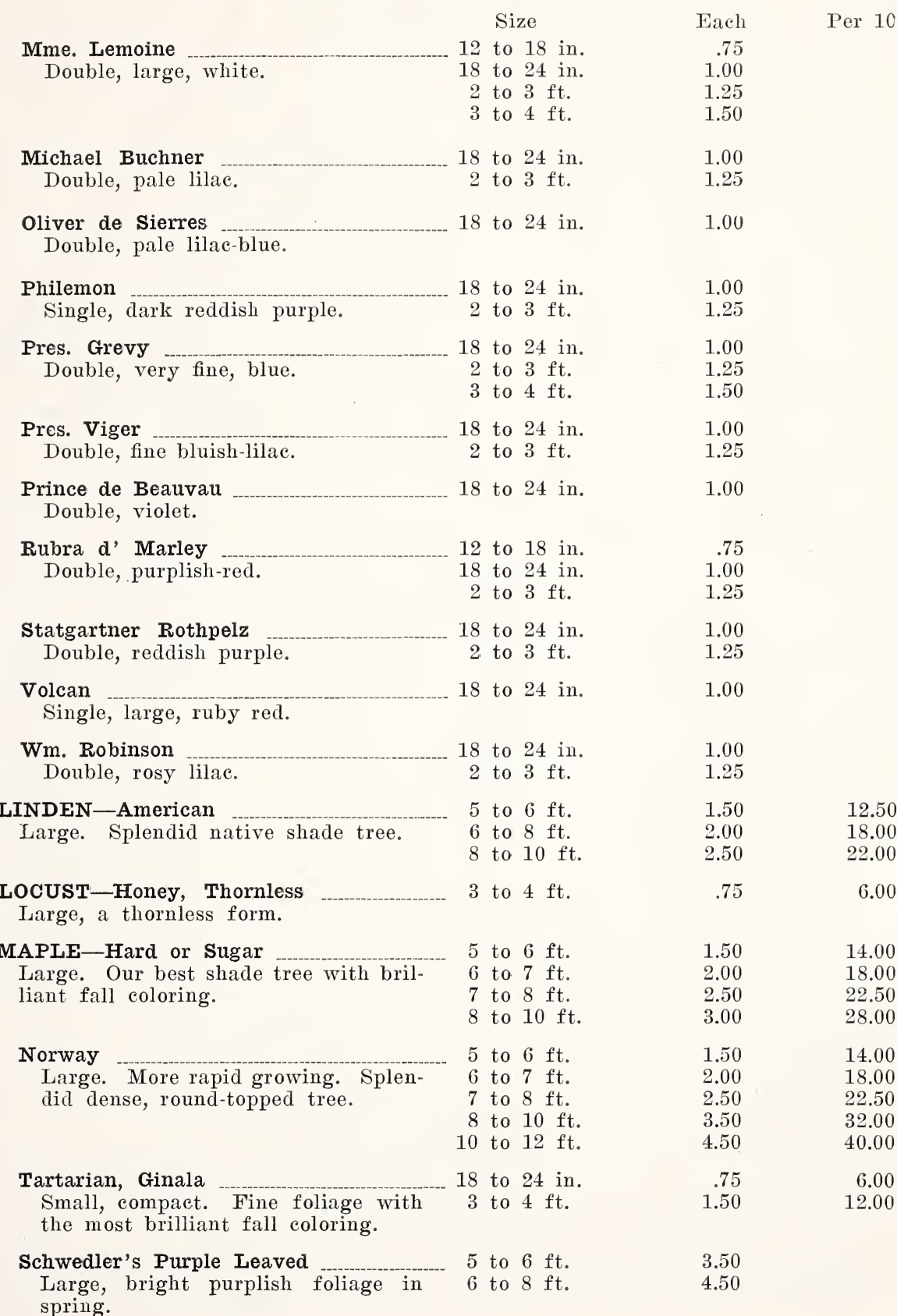




\section{DECIDUOUS TREES AND SHRUBS-Continued}

\begin{tabular}{|c|c|c|c|}
\hline $\begin{array}{l}\text { Weir's Cut Leaved Weeping } \\
\text { Large. Finely cut-leaved form of } \\
\text { the Soft Maple. }\end{array}$ & $\begin{array}{l}\text { Size } \\
4 \text { to } 5 \mathrm{ft} \text {. } \\
5 \text { to } 6 \mathrm{ft} \text {. } \\
6 \text { to } 8 \mathrm{ft} \text {. } \\
8 \text { to } 10 \mathrm{ft} \text {. }\end{array}$ & $\begin{array}{c}\text { Each } \\
1.25 \\
1.50 \\
2.00 \\
2.50\end{array}$ & Per 10 \\
\hline $\begin{array}{l}\text { MOUNTAIN ASH-European } \\
\text { Medium. Upright; whitish flower } \\
\text { clusters in spring and orange or red } \\
\text { berries late in the fall. }\end{array}$ & $\begin{array}{l}4 \text { to } 5 \mathrm{ft} . \\
5 \text { to } 6 \mathrm{ft} . \\
6 \text { to } 7 \mathrm{ft} . \\
7 \text { to } 8 \mathrm{ft} \\
8 \text { to } 10 \mathrm{ft} .\end{array}$ & $\begin{array}{r}.75 \\
1.00 \\
1.25 \\
1.50 \\
2.00\end{array}$ & $\begin{array}{r}6.00 \\
9.00 \\
11.00 \\
12.50 \\
17.50\end{array}$ \\
\hline Oak Leaved & 6 to $7 \mathrm{ft}$. & 2.00 & \\
\hline $\begin{array}{l}\text { MULBERRY-Russian } \\
\text { Medium, rapid growing tree, bearing } \\
\text { fruit much prized by birds in June. } \\
\text { Extensively planted in places for } \\
\text { hedges and windbreaks. }\end{array}$ & $\begin{array}{l}3 \text { to } 4 \mathrm{ft} . \\
4 \text { to } 5 \mathrm{ft} . \\
5 \text { to } 6 \mathrm{ft} .\end{array}$ & $\begin{array}{l}.40 \\
.50 \\
.60\end{array}$ & $\begin{array}{l}3.50 \\
4.00 \\
5.00\end{array}$ \\
\hline $\begin{array}{l}\text { Weeping } \\
\text { Grafted on the upright form } 5 \text { or } 6 \\
\text { feet high. }\end{array}$ & $\begin{array}{l}2 \text {-year heads } \\
1 \text {-year heads }\end{array}$ & $\begin{array}{l}5.00 \\
4.00\end{array}$ & \\
\hline $\begin{array}{l}\text { OAK-Burr } \\
\text { Large. One of our sturdiest native } \\
\text { trees. }\end{array}$ & $\begin{aligned} 6 & \text { to } 7 \mathrm{ft} . \\
7 & \text { to } 8 \mathrm{ft} \\
8 & \text { to } 10 \mathrm{ft} . \\
10 & \text { to } 12 \mathrm{ft} .\end{aligned}$ & $\begin{array}{l}2.50 \\
3.00 \\
4.00 \\
5.00\end{array}$ & $\begin{array}{l}24.00 \\
28.00 \\
36.00 \\
45.00\end{array}$ \\
\hline $\begin{array}{l}\text { Pin } \\
\text { Large. Rapid growing with brilliant } \\
\text { fall foliage retained late. }\end{array}$ & $\begin{array}{l}5 \text { to } 6 \mathrm{ft} . \\
6 \text { to } 7 \mathrm{ft} . \\
7 \text { to } 8 \mathrm{ft} . \\
8 \text { to } 10 \mathrm{ft} \text {. }\end{array}$ & $\begin{array}{l}2.25 \\
3.00 \\
4.00 \\
5.00\end{array}$ & $\begin{array}{l}20.00 \\
25.00 \\
35.00 \\
45.00\end{array}$ \\
\hline $\begin{array}{l}\text { OLIVE-Russian } \\
\text { Medium, leaves and young twigs cov- } \\
\text { ered with silvery scales. Fragrant } \\
\text { yellow flowers in spring. Silvery } \\
\text { coated berries in fall. May be trimmed } \\
\text { into a fine tall hedge. }\end{array}$ & $\begin{array}{l}3 \text { to } 4 \mathrm{ft} . \\
4 \text { to } 5 \mathrm{ft} . \\
5 \text { to } 6 \mathrm{ft} . \\
6 \text { to } 7 \mathrm{ft} .\end{array}$ & $\begin{array}{r}.60 \\
.75 \\
1.00 \\
1.25\end{array}$ & $\begin{array}{r}5.00 \\
7.00 \\
9.00 \\
11.00\end{array}$ \\
\hline $\begin{array}{l}\text { PEARI BUSH, Exochordia } \\
6 \text { to } 10 \mathrm{ft.} \text { Pearl-like buds opening } \\
\text { pure white in May. }\end{array}$ & 2 to $3 \mathrm{ft}$. & 1.00 & 9.00 \\
\hline $\begin{array}{l}\text { PERSIMMON, From Iowa Seed } \\
\text { Small tree with splendid foliage and } \\
\text { bearing edible fruit late in fall. }\end{array}$ & $\begin{array}{l}3 \text { to } 4 \mathrm{ft} . \\
4 \text { to } 5 \mathrm{ft} . \\
5 \text { to } 6 \mathrm{ft} .\end{array}$ & $\begin{array}{l}1.00 \\
1.50 \\
2.00\end{array}$ & $\begin{array}{r}9.00 \\
12.50 \\
16.00\end{array}$ \\
\hline $\begin{array}{l}\text { PHILADELPHUS, Mockorange; Syringa. } \\
\text { Avalanche } \\
4 \text { to } 6 \mathrm{ft} \text {. Very fragrant. }\end{array}$ & 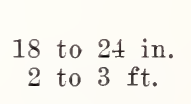 & .50 & $\begin{array}{l}4.50 \\
6.50\end{array}$ \\
\hline $\begin{array}{l}\text { Banniere } \\
6 \text { to } 10 \mathrm{ft} \text {. Tall, semi-double, very } \\
\text { early. }\end{array}$ & $\begin{array}{r}18 \text { to } 24 \mathrm{in} . \\
2 \text { to } 3 \mathrm{ft} \text {. } \\
3 \text { to } 4 \mathrm{ft} \text {. }\end{array}$ & $\begin{array}{l}.50 \\
.60 \\
.75\end{array}$ & $\begin{array}{l}4.00 \\
5.00 \\
6.00\end{array}$ \\
\hline $\begin{array}{l}\text { Bouquet Blanc } \\
4 \text { to } 6 \mathrm{ft} \text {. Double flowers. }\end{array}$ & $\begin{array}{l}2 \text { to } 3 \mathrm{ft} . \\
3 \text { to } 4 \mathrm{ft} \text {. }\end{array}$ & $\begin{array}{l}1.00 \\
1.25\end{array}$ & $\begin{array}{r}8.00 \\
10.00\end{array}$ \\
\hline $\begin{array}{l}\text { Coronarius the common Mockorange } \\
8 \text { to } 10 \mathrm{ft} \text {. Very fragrant. }\end{array}$ & 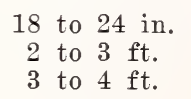 & $\begin{array}{l}.40 \\
.50 \\
.60\end{array}$ & $\begin{array}{l}3.50 \\
4.50 \\
5.50\end{array}$ \\
\hline
\end{tabular}




\section{DECIDUOUS TREES AND SHRUBS-Continued}

\begin{tabular}{|c|c|c|c|}
\hline Coronarius nana, $3 \mathrm{ft}$. bush & $\begin{array}{l}\text { Size } \\
18 \text { to } 24 \mathrm{in} .\end{array}$ & $\begin{array}{c}\text { Each } \\
1.00\end{array}$ & Per 10 \\
\hline $\begin{array}{l}\text { Golden, Aurea } \\
\text { Dwarf, golden leaves, compact, } \\
\text { flower's small. }\end{array}$ & $\begin{aligned} 12 & \text { to } 15 \mathrm{in} . \\
15 & \text { to } 18 \mathrm{in} . \\
2 & \text { to } 21 / 2 \mathrm{ft} .\end{aligned}$ & $\begin{array}{r}.60 \\
.75 \\
1.25\end{array}$ & $\begin{array}{r}5.00 \\
7.00 \\
11.00\end{array}$ \\
\hline $\begin{array}{l}\text { Virginale } \\
6 \text { to } 8 \mathrm{ft} \text {. Very large, very frag- } \\
\text { rant, flowers over a long season. }\end{array}$ & $\begin{aligned} 18 & \text { to } 24 \mathrm{in} . \\
2 & \text { to } 3 \mathrm{ft} .\end{aligned}$ & $\begin{array}{r}.75 \\
1.00\end{array}$ & $\begin{array}{l}7.00 \\
9.00\end{array}$ \\
\hline $\begin{array}{l}\text { HOTINIA villosa, Christmas berry } \\
\text { Shrub, } 5 \text { to } 8 \mathrm{ft} \text {., corymbs of white } \\
\text { flowers in June; brilliant fall foliage } \\
\text { and scarlet berries till midwinter. }\end{array}$ & $\begin{array}{l}2 \text { to } 3 \mathrm{ft} . \\
3 \text { to } 4 \mathrm{ft} .\end{array}$ & $\begin{array}{l}1.00 \\
1.25\end{array}$ & $\begin{array}{r}8.00 \\
10.00\end{array}$ \\
\hline $\begin{array}{l}\text { HYSOCARPUS opulifolia aurea, Nine- } \\
\text { bark; or Golden Spirea } \\
\text { Shrub } 8 \text { to } 10 \mathrm{ft} \text {. White flowers and } \\
\text { red seed pods. }\end{array}$ & $\begin{array}{r}18 \text { to } 24 \mathrm{in} . \\
2 \text { to } 3 \mathrm{ft} . \\
3 \text { to } 4 \mathrm{ft} . \\
4 \text { to } 5 \mathrm{ft} .\end{array}$ & $\begin{array}{l}.40 \\
.50 \\
.60 \\
.90\end{array}$ & $\begin{array}{l}3.50 \\
4.00 \\
5.00 \\
8.00\end{array}$ \\
\hline $\begin{array}{l}\text { Monygonma } \\
4 \text { to } 6 \mathrm{ft} \text {., compact bush, elear green } \\
\text { foliage. }\end{array}$ & 18 to $24 \mathrm{in}$. & .50 & 4.00 \\
\hline $\begin{array}{l}\text { OPLAR-Carolina } \\
\text { Large, most rapid growing poplar. } \\
\text { Smaller sizes under Forest Tree Seed- } \\
\text { lings. }\end{array}$ & $\begin{array}{r}5 \text { to } 6 \mathrm{ft} . \\
6 \text { to } 8 \mathrm{ft} . \\
8 \text { to } 10 \mathrm{ft} . \\
10 \text { to } 12 \mathrm{ft} .\end{array}$ & $\begin{array}{r}.40 \\
.50 \\
.75 \\
1.00\end{array}$ & $\begin{array}{l}3.00 \\
4.00 \\
6.00 \\
9.00\end{array}$ \\
\hline $\begin{array}{l}\text { Lombardy } \\
\quad \text { Large, strictly fastigiate habit. }\end{array}$ & $\begin{array}{r}5 \text { to } 6 \mathrm{ft.} \\
6 \text { to } 8 \mathrm{ft} . \\
8 \text { to } 10 \mathrm{ft} . \\
10 \text { to } 12 \mathrm{ft} .\end{array}$ & $\begin{array}{r}.75 \\
1.00 \\
1.25 \\
1.50\end{array}$ & $\begin{array}{r}5.00 \\
8.00 \\
10.00 \\
14.00\end{array}$ \\
\hline $\begin{array}{l}\text { PTENTILLA Fruticosa } \\
\text { Shrub } 1 \text { to } 4 \mathrm{ft} \text {. Bright yellow flowers }\end{array}$ & $\begin{array}{l}12 \text { to } 18 \mathrm{in} . \\
18 \text { to } 24 \mathrm{in} .\end{array}$ & .40 & $\begin{array}{l}3.00 \\
4.00\end{array}$ \\
\hline
\end{tabular}

PRIVETS-See under Hedge Plants.

\section{PRUNUS-Cestena, Hansen's Purple}

Leaved Small. Bright reddish purple foliage throughout the season.

Glandulosa, Flowering Almonds Small shrubs, double flowers before. the leaves, either white or pink.

Padus, May Day Tree European Bird Cherry. Medium tree. Must be planted very early. 18 to $24 \mathrm{in}$

Pennsylvanica, Wild Bird Cherry Medium, rapid growing, bears bright red fruit in clusters.

\section{Serotina} Medium. Our native wild black cherry. Attractive in flower and fruit with good fall coloring.
3 to $4 \mathrm{ft}$.

4 to $5 \mathrm{ft}$.

5 to $6 \mathrm{ft}$. 2 to $3 \mathrm{ft}$. 3 to $4 \mathrm{ft}$. 4 to $5 \mathrm{ft}$. 5 to $6 \mathrm{ft}$. 


\section{DECIDUOUS TREES AND SHRUBS-Continued}

Siberica, Siberian Almond

Size

Each

Per 10

Shrub, $3 \mathrm{ft}$, single pink flowers, 18 to $24 \mathrm{in}$.

.75

1.00

7.00

very early.

Subhirtella and other Japanese Flowering Cherries can be furnished in limited quantities. Write for special list.

Tomentosa, Nanking Cherry 18 to $24 \mathrm{in}$.

Small. Pink buds and white flowers, 2 to $3 \mathrm{ft}$.

RHODOTYPHUS kerroides, Jetbead,

White Kerria

ROSE ACACIA, Robinia hispida 18 to $24 \mathrm{in}$. Spreading 2 to $4 \mathrm{ft}$, bristly branches, 2 to $3 \mathrm{ft}$.

\section{Tree form}

Grafted on Locust stems, 3 to $4 \mathrm{ft}$.

SNOWBALL, Viburnum opulis sterilis 12 to $18 \mathrm{in.}$

Well known shrub, 5 to $8 \mathrm{ft}$.

18 to $24 \mathrm{in}$.

\section{SNOWBERRY, Symphoricarpos} racemosus

SORBARIA sorbifolia, False Spirea,

\section{SPIREA}

Anthony Waterer Pink, very dwarf.

12 to 15 in. 15 to 18 in. 18 to $24 \mathrm{in}$.

arguta 18 to $24 \mathrm{in}$. 3 to $6 \mathrm{ft}$. Very early, white flowers. 2 to $3 \mathrm{ft}$. 


\section{DECIDUOUS TREES AND SHRUBS-Continued}

\begin{tabular}{|c|c|c|c|}
\hline & Size & Each & Per 10 \\
\hline $\begin{array}{l}\text { callosa alba } \\
2 \text { to } 3 \mathrm{ft} \text {. Dwarf, white. }\end{array}$ & 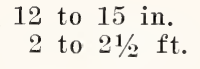 & $\begin{array}{l}.45 \\
.75\end{array}$ & $\begin{array}{l}4.00 \\
7.00\end{array}$ \\
\hline $\begin{array}{l}\text { froebeli } \\
2 \text { to } 3 \mathrm{ft} ., \text { pink, dwarf, new growth } \\
\text { pinkish. }\end{array}$ & $\begin{array}{l}12 \text { to } 18 \text { in. } \\
18 \text { to } 24 \text { in. }\end{array}$ & $\begin{array}{l}.30 \\
.45\end{array}$ & $\begin{array}{l}2.50 \\
3.50\end{array}$ \\
\hline $\begin{array}{l}\text { thunbergi } \\
2 \text { to } 4 \text { ft. Very fine foliage and } \\
\text { twigs, early, white. }\end{array}$ & $\begin{aligned} 18 & \text { to } 24 \mathrm{in} . \\
2 & \text { to } 3 \mathrm{ft} .\end{aligned}$ & $\begin{array}{l}.50 \\
.60\end{array}$ & $\begin{array}{l}4.50 \\
5.50\end{array}$ \\
\hline $\begin{array}{l}\text { vanhoutti, Bridal Wreath } \\
5 \text { to } 7 \mathrm{ft} \text {. Common Spirea. Light } \\
\text { grade for hedge planting quoted on } \\
\text { request. }\end{array}$ & $\begin{array}{r}12 \text { to } 18 \mathrm{in} . \\
18 \text { to } 24 \mathrm{in} . \\
2 \text { to } 3 \mathrm{ft} . \\
3 \text { to } 4 \mathrm{ft} .\end{array}$ & $\begin{array}{l}.25 \\
.35 \\
.45 \\
.60\end{array}$ & $\begin{array}{l}2.00 \\
3.00 \\
4.00 \\
5.00\end{array}$ \\
\hline $\begin{array}{l}\text { UMAC, Rhus } \\
\text { Aromatic, R. canadensis } \\
2 \text { to } 4 \mathrm{ft} \text {. Fragrant Sumac. }\end{array}$ & $\begin{array}{r}12 \text { to } 18 \mathrm{in} . \\
18 \text { to } 24 \mathrm{in} . \\
2 \text { to } 3 \mathrm{ft} .\end{array}$ & $\begin{array}{r}.50 \\
.75 \\
1.00\end{array}$ & $\begin{array}{l}4.00 \\
6.50 \\
-\end{array}$ \\
\hline $\begin{array}{l}\text { Staghorn Cut Leaved, R. typhina } \\
\text { lacinata } \\
\text { Shrub up to } 16 \mathrm{ft} \text {. Twigs velvety; } \\
\text { foliage very finely cut. }\end{array}$ & $\begin{aligned} 18 & \text { to } 24 \mathrm{in} . \\
2 & \text { to } 3 \mathrm{ft} . \\
3 & \text { to } 4 \mathrm{ft} .\end{aligned}$ & $\begin{array}{l}.40 \\
.50 \\
.75\end{array}$ & $\begin{array}{l}3.50 \\
4.50 \\
7.00\end{array}$ \\
\hline $\begin{array}{l}\text { YCAMORE-American } \\
\text { Large, grayish-green smooth bark. } \\
\text { Splendid shade tree. }\end{array}$ & $\begin{array}{l}4 \text { to } 5 \mathrm{ft} . \\
5 \text { to } 6 \mathrm{ft} . \\
6 \text { to } 8 \mathrm{ft} .\end{array}$ & $\begin{array}{l}1.00 \\
1.50 \\
2.00\end{array}$ & $\begin{array}{r}9.00 \\
14.00 \\
18.00\end{array}$ \\
\hline $\begin{array}{l}4 \text { to } 8 \mathrm{ft} \text {. Foliage feathery, flowers } \\
\text { pink. }\end{array}$ & $\begin{aligned} 18 & \text { to } 24 \mathrm{in} . \\
3 & \text { to } 4 \mathrm{ft} .\end{aligned}$ & $\begin{array}{l}.40 \\
.60\end{array}$ & $\begin{array}{l}3.00 \\
5.00\end{array}$ \\
\hline $\begin{array}{l}\text { SHORN-Paul's Double Scarlet } \\
\text { Small tree. Very double, deep crim- } \\
\text { son flowers. }\end{array}$ & $-\begin{array}{l}4 \text { to } 5 \mathrm{ft} . \\
5 \text { to } 6 \mathrm{ft} .\end{array}$ & $\begin{array}{l}2.50 \\
3.00\end{array}$ & $\begin{array}{l}24.00 \\
28.00\end{array}$ \\
\hline $\begin{array}{l}\text { TIBURNUM-See also Snowball and } \\
\text { Cranberry. } \\
\text { carlesi } \\
3 \text { to } 5 \text { ft. Pinkish-white, very fra- } \\
\text { grant and rare. }\end{array}$ & $\begin{array}{l}12 \text { to } 15 \text { in. } \\
15 \text { to } 18 \text { in. } \\
18 \text { to } 24 \text { in. }\end{array}$ & $\begin{array}{l}2.00 \\
2.50 \\
3.00\end{array}$ & \\
\hline $\begin{array}{l}\text { Cassinoides, Witherod } \\
5 \text { to } 7 \mathrm{ft.} \text { Pink fruit changing to } \\
\text { blue. Brilliant fall foliage. }\end{array}$ & $\begin{aligned} 18 & \text { to } 24 \mathrm{in} . \\
2 & \text { to } 3 \mathrm{ft} .\end{aligned}$ & $\begin{array}{r}.80 \\
1.00\end{array}$ & $\begin{array}{l}7.00 \\
9.00\end{array}$ \\
\hline $\begin{array}{l}\text { dentatum, Arrowwood } \\
\text { Shrub } 8 \text { to } 10 \mathrm{ft} \text {. Succeeds in all } \\
\text { locations and colors brilliantly in } \\
\text { fall. }\end{array}$ & $\begin{array}{r}12 \text { to } 18 \mathrm{in} . \\
18 \text { to } 24 \mathrm{in} . \\
2 \text { to } 3 \mathrm{ft} . \\
3 \text { to } 4 \mathrm{ft} .\end{array}$ & $\begin{array}{l}.40 \\
.50 \\
.60 \\
.75\end{array}$ & $\begin{array}{l}3.50 \\
4.50 \\
5.50 \\
7.00\end{array}$ \\
\hline $\begin{array}{l}\text { lantana, Wayfaring Tree } \\
\text { Shrub } 10 \text { to } 15 \mathrm{ft} \text {. Thick rugose } \\
\text { foliage, almost evergreen. }\end{array}$ & $\begin{aligned} 18 & \text { to } 24 \mathrm{in} . \\
2 & \text { to } 3 \mathrm{ft} .\end{aligned}$ & $\begin{array}{r}.75 \\
1.00\end{array}$ & $\begin{array}{l}7.00 \\
9.00\end{array}$ \\
\hline $\begin{array}{l}\text { lentago, Sheepberry } \\
\text { Bush to } 15 \mathrm{ft} \text { or more. Splendid }\end{array}$ & $\begin{array}{l}2 \text { to } 3 \mathrm{ft} . \\
3 \text { to } 4 \mathrm{ft} .\end{array}$ & $\begin{array}{l}1.00 \\
1.25\end{array}$ & $\begin{array}{r}9.00 \\
11.00\end{array}$ \\
\hline
\end{tabular}
foliage and edible fruit. 


\section{DECIDUOUS TREES AND SHRUBS-Continued}

\begin{tabular}{|c|c|c|c|}
\hline FIGFIIA & Size & Each & Per 10 \\
\hline Eva Rathke & 18 to 24 in & $\tau-$ & \\
\hline Rich reddish-purple. 4 to $5 \mathrm{ft}$. & 2 to $3 \mathrm{ft}$. & 1.00 & 9.00 \\
\hline $\begin{array}{l}\text { Rosea } \\
4 \text { to } 6 \mathrm{ft} \text {. Bright pink. Not fully } \\
\text { hardy. }\end{array}$ & $\begin{aligned} 18 & \text { to } 24 \mathrm{in} . \\
2 & \text { to } 3 \mathrm{ft} .\end{aligned}$ & .60 & $\begin{array}{l}5.00 \\
6.50\end{array}$ \\
\hline $\begin{array}{l}\text { WILLow-Laurel Leaved } \\
\text { Medium. Broad tree. Shining dark } \\
\text { green, broad leares. }\end{array}$ & $\begin{array}{l}5 \text { to } 6 \mathrm{ft} . \\
6 \text { to } 8 \mathrm{ft} . \\
8 \text { to } 10 \mathrm{ft} .\end{array}$ & $\begin{array}{r}.75 \\
1.00 \\
1.25\end{array}$ & $\begin{array}{r}6.00 \\
8.00 \\
10.00\end{array}$ \\
\hline $\begin{array}{l}\text { Niobe Weeping } \\
\text { Large tree. Golden yellow bark, } \\
\text { very long pendulous branches. }\end{array}$ & $\begin{array}{l}5 \text { to } 6 \mathrm{ft} . \\
6 \text { to } 8 \mathrm{ft} \\
8 \text { to } 10 \mathrm{ft} .\end{array}$ & $\begin{array}{r}.90 \\
1.25 \\
1.50\end{array}$ & $\begin{array}{r}8.00 \\
11.00 \\
12.50\end{array}$ \\
\hline $\begin{array}{l}\text { Pussy } \\
\quad \text { Small tree. Large, showy catkins. }\end{array}$ & $\begin{array}{l}3 \text { to } 4 \mathrm{ft} . \\
4 \text { to } 5 \mathrm{ft} .\end{array}$ & $\begin{array}{l}.75 \\
.90\end{array}$ & $\begin{array}{l}6.50 \\
7.50\end{array}$ \\
\hline $\begin{array}{l}\text { Ural, Siberian Hedgewood } \\
\text { Compact bush, } 8 \text { to } 10 \mathrm{ft} \text {. Reddish } \\
\text { twigs, bluish-green leares. }\end{array}$ & $\begin{aligned} 18 & \text { to } 24 \mathrm{in} . \\
2 & \text { to } 3 \mathrm{ft} \text {. }\end{aligned}$ & .50 & $\begin{array}{l}4.00 \\
6.00\end{array}$ \\
\hline
\end{tabular}

\section{HEDGE PLANTS}

(See also Arborvitae and Spruce under Evergreens, and Russian Mulberry under Forest Tree Seedlings)

BARBERRY, Japanese, Berberis thunbergi

Dense shrub, 2 to $5 \mathrm{ft}$. Brilliant red berries and fall foliage. An unexcelled thorny hedge plant for trimmed or untrimmed hedge.

$\begin{array}{lrrrr} & \text { Size } & \text { Each } & \text { Per } 10 & \text { Per } 100 \\ \text { Seedlings } & 6 \text { to } 9 \mathrm{in.} & - & - & \$ 5.00 \\ \text { Seedlings } & 9 \text { to } 12 \mathrm{in.} & - & & 7.00 \\ \text { 2-year branched } & 12 \text { to } 15 \mathrm{in.} & .25 & \$ 2.00 & 15.00 \\ \text { 2-year branched } & 15 \text { to } 18 \mathrm{in.} & .30 & 2.50 & 22.50 \\ \text { Heary 3-year } & 18 \text { to } 24 \mathrm{in.} & .40 & 3.50 & 30.00 \\ \text { Heary 3-year } & 2 \text { to } 21 / 2 \mathrm{ft} . & .50 & 4.50 & 40.00 \\ \text { Heary 3-year } & 21 / 2 \text { to } 3 \mathrm{ft} & .60 & 5.50 & 50.00\end{array}$

Box, a rery dwarf form of the above

rariety

9 to 12 in

3.00

12 to 15 in.

18 to $24 \mathrm{in}$.

.50

4.50

40.00

Splendid for medium size smooth hedge. Brilliant autumn coloring, per-

fectly hardy.

Seedlings

\section{PRIVETS, Ligustrum}

\section{Amur River North}




\begin{tabular}{|c|c|c|c|c|}
\hline HEDGE PL & TTS-Continued & & & \\
\hline $\begin{array}{l}\text { Ibta } \\
\quad \text { Tall, much branched. }\end{array}$ & \begin{tabular}{l}
\multicolumn{3}{c}{ Size } \\
2 to $3 \mathrm{ft}$. \\
3 to $4 \mathrm{ft}$.
\end{tabular} & $\begin{array}{c}\text { Each } \\
.35 \\
.45\end{array}$ & $\begin{array}{c}\text { Per } 10 \\
3.00 \\
3.50\end{array}$ & $\begin{array}{r}\text { Per } 100 \\
25.00 \\
32.00\end{array}$ \\
\hline $\begin{array}{l}\text { Polish, European, L. vulgare } \\
\text { Upright, hardy, retains its foliage } \\
\text { uncolored very late. }\end{array}$ & $\begin{array}{r}12 \text { to } 18 \mathrm{in} . \\
18 \text { to } 24 \mathrm{in} . \\
2 \text { to } 3 \mathrm{ft} . \\
3 \text { to } 4 \mathrm{ft} .\end{array}$ & $\begin{array}{l}.20 \\
.25 \\
.35 \\
.40\end{array}$ & $\begin{array}{l}1.50 \\
2.00 \\
2.50 \\
3.50\end{array}$ & $\begin{array}{l}12.00 \\
17.50 \\
24.00 \\
30.00\end{array}$ \\
\hline $\begin{array}{l}\text { Regals, True Type } \\
\text { Low, dense shrub, horizontal }\end{array}$ & $\begin{aligned} 18 & \text { to } 24 \mathrm{in} \\
2 & \text { to } 21 / 2 \mathrm{ft}\end{aligned}$ & $\begin{array}{l}.40 \\
.50\end{array}$ & $\begin{array}{l}3.50 \\
4.50\end{array}$ & $\begin{array}{l}30.00 \\
40.00\end{array}$ \\
\hline
\end{tabular}

\section{ROSES}

All plants offered are two-year field-grown bushes. One-half or more of the tops should be cut off and the bushes planted deeper than they stood in the Nursery.

\section{CLIMBING ROSES}

(All need winter protection except as noted)

AMERICAN PILLAR, 75c: Immense clusters; large, single; bright crimson, lighter center.

BALTIMORE BELLE, 50c: Blush-white, an old favorite, rather tender.

CRIMSON RAMBLER, 50c: Bright red, large clusters, the most popular climber. CLIMBING AMERICAN BEAUTY, 75c: Large rich carmine, somewhat fragrant. DR. VAN FLEET, 75c: Light pink, perfectly formed, pointed buds, long stems. DOROTHY PERKINS, 50c: Delicate pink, large clusters, vigorous and healthy. EXCELSA, Red Dorothy Perkins, 50c: Lighter red than Crimson Rambler, but more vigorous.

FLOWER OF FAIRFIELD, 75c: The so-called ever-blooming crimson rambler.

HIAWATHA, 50c: Single, deep crimson with yellow center, very fragrant.

LADY DUNCAN, 90c: Pure pink, cross of Rosa Rugosa and Rosa Wichuriana.

MAX GRAF, 90c: Large, single shining pink, elimbing rugosa. Excellent ground and rock cover, needs no protection.

PAUL'S SCARLET, 90c: Large, bright, pure red, semi-double, in clusters.

PRAIRIE QUEEN, 50c: Large globular, bright pink, one of the hardiest climbers. ROSA SETIGERA, 50c: The wild prairie rose, single light pink flowers and bright red hips.

ROSIERE, 75c: A darker colored Thousand Beauties.

SILVER MOON, 90c: Silvery white with yellow stamens, quite tender.

TAUSENDSCHON, 75c: Large clusters ranging from bright pink to pure white.

WHITE DOROTHY PERKINS, 50c: The hardiest pure white climbing rose.

WICHURIAN, Memorial, 50c: Glossy foliage with very fragrant, creamy white flowers, prostrate grower.

\section{HARDY ROSES}

(Varieties which need no winter protection in Central Iowa)

GROOTENDORST, 90c: Hybrid of Rugosa X Baby Rambler; semi-double, small fringed, bright red roses in clusters produced continually. Perfectly hardy, good hedge variety.

HARRISON YELLOW, 90c: Small bright yellow, early in spring, perfectly hardy. HENRI MARTIN, 75c: Rosy red, mossed heavily, fragrant. 


\section{ROSES-Continued}

HUGONIS, 90c: A tall spring flowering shrub with yellowish flowers and small leaves.

KAMCHATKA, 75c: Double, red form of Rosa Rugosa, less attractive bush.

MAD. PLANTIER, 50c: Pure white, almost thornless, blooms in spring only.

PERSIAN YELLOW, 90c: Deepest yellow, Austrian brier.

ROSA blanda, 75c: Single, pink, 2 to $4 \mathrm{ft}$., splendid shrub, bright red hips.

ROSA lucida, 75c: Bright pink, 4 to $6 \mathrm{ft}$, shining foliage, bright red hips.

ROSA rubrifolia, 75c: A shrubby, perfectly hardy bush with reddish foliage, pink flowers, and a profusion of red hips, prefers partial shade.

ROSA rugosa, 75c: 4 to $7 \mathrm{ft}$., single, large bright red; wrinkled, tough foliage; continuous bloomer, very large crimson hips. Good shrub or hedge plant.

ROSA rugosa alba, 75c: White form of Rosa Rugosa.

SALET, 75c: Moss, large full rose pink.

SEVEN SISTERS, 50c: Double, large, varying from light red to white.

SWEET BRIAR, 90c: Pink flowers, fragrant foliage.

WHITE MOSS, 75c: Large, pure white, fragrant, heavily mossed.

\section{OTHER ROSES}

H. T. means Hybrid Tea; H. P. means Hybrid Perpetual. All these should have winter protection. The Baby Ramblers and H. T.'s are the most constant bloomers.

AMERICAN BEAUTY, 90c: H. P., large globe shaped, crimson.

BABY RAMBLERS, Polyanthas.

Named Varietiese:

Clotilde Soupert, 90c: Very full, pearly white shaded pink.

Gruss an Aachen, 90c: Very large, light rose overlaid with yellow.

Jessie, 90c: Glowing crimson with white eye.

Lafayette, 90c: Large brilliant cherry-crimson flowers continuously.

Orleans, 90c: Geranium red with rose tint.

COLUMBIA, 90c: H. T., large, fragrant, continuous blooming, bright pink.

CONRAD F. MEYER, 90c: Hybrid Rugosa, delicate pink, tall upright grower.

EDWARD MAWLEY, 90c: H. T., very dark velvety erimson, most fragrant.

ETOILE De FRANCE, 90c: H. T., large cupped, velvety crimson, very fragrant.

FRAU KARL DRUSCHKI, 75c: H. P., the very purest white, continuous bloomer. GEN. JACQUEMINOT, 75c: H. P., scarlet-crimson, early and fragrant.

GEN. McARTHUR, 90c: H. T., sweetly scented, brilliant erimson scarlet, very free bloomer.

GEO. ARENDS, 90c: H. P., large, fragrant, pink, ealled "Pink Druschki." Excellent.

GRUSS AN TEPLITZ, 90c: H. T., clear crimson-scarlet, the most continuous bloomer.

J. B. CLARK, 75c: H. P., very large, intense scarlet; vigorous grower.

JOHN HOPPER, 75c: H. P., large rosy red, fragrant, medium grower.

LADY HLLINGDON, 90c: H. T., long pointed buds opening apricot yellow.

LOLITA ARMOUR, 90c: Pernetiana, large, fragrant, chrome-yellow at base shading to bright salmon.

LOS ANGELES, 90c: H. T., coral pink shaded coppery gold, moderately hardy.

LUXEMBURG, 90c: H. T., large, rich coppery yellow, vigorous and free blooming.

MAGNA CHARTA, 75c: H. P., very large, rosy pink, tinted carmine.

MRS. JOHN LAING, 75c: Large, soft pink, pointed buds, vigorous grower. 


\section{ROSES-Continued}

MME. BUTTERFLY, 90c: H. T., a more brilliant Ophelia, continuous bloomer. OPHELIA, 90c: H. 'T., salmon-flesh, fragrant, long stems, very productive. PAUL NEYRON, 75c: H. P., very largest, clear pink, fragrant, thornless. PRINCE CAMILLE De ROHAN, 75c: H. P., dark blood red, large, fragrant, rather weak grower.

RADIANCE, 90c: H. T., fine salmon pink, long stems, very productive.

RED RADIANCE, 90c: H. T., deep red, finest form, extremely productive.

ROSE MARIE, 90c: H. T., clear rose pink, long pointed buds.

SUNBURST, 90c: H. T., bright orange yellow with paler edge.

SOLEIL D' OR, 90c: Orange yellow varying to ruddy gold, not continuous.

SOUV. D' CLAUDIUS PERNET, per. 90c: H. T., deep yellow, considered the best deep yellow rose.

ULRICH BRUNER, 75c: H. P., large, fragrant, eherry red, vigorous.

WILLOWMERE PER., 90c: Very large, double, rich shrimp pink shaded yellow.

\section{CLIMBING VINES}

(Two-year No. 1 plants except as noted)

AMPELOPSIS, IVy

$\begin{array}{lrr} & \text { Each } & \text { Per } 10 \\ \text { Englemanni-Clings to smoothest walls, hardiest } & \$ 0.50 & \$ 4.00 \\ \text { Medium grade } & .35 & 2.50 \\ \text { Veitchii, Boston Ivy-More refined but less hardy } & 1.00 & 9.00 \\ \text { Medium grade } & .75 & 6.00\end{array}$

ARISTOLOCHIA, Dutchman's Pipe, large leaf 1.25

“ “ small leaf .60

BITTERSWEET, Celastrus scandens, native bittersweet $\quad .50$

CLEMATIS-Coccinia, fleshy, bell-shaped red flower ____ .50

Henryi, large, white 1.25

Jackmanni, large, purple

Mad. Ed. Andre, large, wine red $\quad 1.25$

HONEYSUCKLE-Scarlet Trumpet, continuous bloomer, almost

evergreen

HOP VINE 


\section{PEONIES}

We do not keep a stock of the more expensive varieties in storage for spring planting, so any order for them will be held till fall, which is the very best time to plant peonies.

Prices are for standard divisions of 3 to 5 eyes or buds. Undivided clumps figured on this basis.

ASA GRAY, \$1.00: Semi-rose type, mid-season, pink with carmine dots.

ADOLPHE ROSSEAU, \$1.50: Semi-double, early, brilliant red.

AGNES M. KELWAY, 40c: Crown type, early, pale rose with creamy center.

AVALANCHE, \$1.00: Crown type, late, very fine milk white.

AUGUSTIN D'HOUR, 75c: Bomb type, tall, mid-season, rich scarlet purple.

BARONESS SCHROEDER, \$1.25: Rose type, late, flesh color fading white.

COUROUNE D' OR, 50c: Semi-rose type, late, white with yellow stamens.

CLAIRE DUBOIS, \$1.00: Rose type, tall, late, fine pink with glossy reflex.

DELACHEI, 75c: Rose type, late, brilliant dark maroon.

DENIS HELYE, 50c: Semi-rose type, mid-season brilliant red.

EDULIS SUPERBA, 50c: Crown type, very early, bright pink.

ENCHANTRESSE, \$5.00: Rose type, very late, creamy white.

ELWOOD PLEAS, \$4.00: Rose type, late mid-season, tall, light shell-pink.

FESTIVA MAXIMA, 50c: Rose type, early, pure white, tipped carmine.

FRANCOISE ORTEGAT, 75c: Semi-rose type, mid-season, deep crimson.

FELIX CROUSSE, 75c: Rose type, late mid-season, bright ruby red.

FRAGRANS, 40c: Bomb type, mid-season, deep pink.

GOLDEN HARVEST, 40c: Bomb type, mid-season, pink, creamy white center.

GRANDIFLORA, 50c: Rose type, late, very bright pink.

GROVER CLEVELAND, \$1.00: Rose type, late, large, dark crimson.

H. F. REDDICK, \$1.00: Semi-rose type, mid-season, brilliant crimson.

JENNY LIND, \$1.00: Bomb type, tall, mid-season, light pink interspersed with white.

JUBILEE, \$4.00: Rose type, very tall, white with delicate pink center.

KARL ROSENFIELD, \$1.25: Semi-rose type, mid-season, rich blood red.

IE CYGNE, \$15.00: Rose type, pure white, has the very highest rating.

LADY ALEXANDER DUFF, \$3.50: Rose type, early, pink fading white.

LATULIP, 50c: Semi-rose type, flesh pink fading white, red markings.

I' ESPERANCE, 50c: Rose type, very early, rose pink.

LIVINGSTONE, 75c: Rose type, late, deep pink, fine cut flower.

LONGFELLOW, \$5.00: Semi-rose type, the most brilliant red.

LOUIS VAN HOUTTI, 75c: Semi-rose type, bright violaceaus red.

LORA DEXHEIMER, \$2.50: Semi-rose type, intense crimson, early.

MARIE LEMOINE, \$1.00: Rose type, very late, ivory white.

MARTHA BULLOCK, \$10.00: Rose type, tall, very large rosy pink.

MAD. CHAUMY, 40c: Rose type, very late, bright rose.

MARECHAL VALLIANT, 50c: Rose type, very large, late, purplish red.

MILTON HILL, \$3.50: Globular, compact, rose type. Late, pale lilac-rose.

MIREILLE, \$1.00: Rose type, very late, milk white.

MAD. DE VERNEVILLE, 50c: Bomb type, mid-season, white, very choice.

MAD. EMILE GALLE, \$1.00: Rose type, late, pale pink, shaded lilac-rose.

MON. JULES ELIE, \$1.00: Bomb type, mid-season, glossy pink, extra fine.

MONS. MARTIN CAHUZAC, \$2.50: Semi-rose type, early, darkest deep maroon.

MODISTE GUERIN, 75c: Bomb type, mid-season, deep lustrous pink.

OFFICINAIIS RUBRA PLENA, \$1.00: Very earliest, bright crimson. 


\section{PEONIES-Continued}

OFFICINALIS ROSEA, \$1.50: Very earliest, rose pink. OFFICINALIS TENUIFOLIA, \$1.50: Fern leaved, very earliest, bright crimson. PASTEUR, \$2.00: Rose type, mid-season, very soft pink. PRES. ROOSEVELT, \$1.00: Semi-rose type, mid-season, deep red. PRIMEVERE, \$3.00: Bomb type, mid-season, tall, creamy yellow. RACHEL, \$1.00: Rose type, mid-season, brightest ruby red. RICHARD CARVEL, \$4.00: Bomb type, early, very bright erimson. ROSA BONHEUR, \$4.50: Rose type, dwarf, light violet rose flecked crimson. RUBRA TRIUMPHANS, 50c: Semi-double, early, red with yellow stamens. SOLANCE, \$4.00: Rose type, mid-season, white shaded salmon. THERESE, \$4.50: Rose type, mid-season, delicate satiny pink. TOURANGELLE, $\$ 5.00$ : Rose type, late, ereamy buff with salmon tints. WALTER FAXSON, \$5.00: Semi-rose type, mid-season, distinct bright salmon rose.

\section{SINGLE AND JAPANESE VARIETIES}

AKALU, \$2.00: Japanese, carmine red with center saffron yellow, striped carmine. ANOMALE, \$2.00: Single, bright red, very earliest. GERALDINE, \$1.50: Japanese, deep carmine violet.

KING OF ENGLAND, \$4.00: Japanese, rich ruby-red with narrow golden center petals.

MIKADO, \$1.50: Japanese, dark crimson with center crimson tipped gold.

OFFICINALIS TENUIFOLIA ROSEA, \$1.00: Single, pink.

SNOW WHEEL \$4.00: Japanese, pure white throughout.

STANLEY, \$1.00: Single, large, dark brilliant erimson.

SINGLE RED, 50c: Unnamed, very early.

THE_BRIDE, \$1.00: Single, large, white with yellow center.

\section{HARDY PHLOX}

The following varieties, mostly $\mathrm{P}$. paniculata, like rich, moist, but well drained soil and a mulching of well rotted manure in winter:

\begin{tabular}{|c|c|c|}
\hline & Each & Per 10 \\
\hline BARON VON DEDUM, orange-red tinted old rose & $\$ 0.30$ & \\
\hline CHAMPS ELYSEE, very dark purplish erimson & .30 & 2.50 \\
\hline O. WIJERS, white with large erimson eye & .30 & 2.5 \\
\hline JULES SANDEAU, large delicate salmon pink, dwarf & .30 & \\
\hline IISS IINGARD, very early, long spike, waxy pure white & .30 & 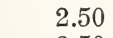 \\
\hline KINS, large, white, tall & .30 & 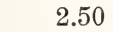 \\
\hline PROF. VIRCHOU, brilliant carmine overlaid with orange scarlet. & .30 & \\
\hline R. P. STRUTHERS, cherry red with claret red eye & .30 & \\
\hline IJNSTROOM, solid bright rose pink & .30 & 2. \\
\hline PECIAL FRANCE, delicate rose with carmine rose eye & .30 & \\
\hline ON HOCHBERG, tl & .30 & 2. \\
\hline T. C. EGAN, very la & .30 & \\
\hline
\end{tabular}

\section{OTHER SPECIES}

AMOENA, 4 in., pink mass in spring

DIVARICATA

Canadensis, lavender, April-May, likes some shade ____ .30

Canadensis Lapham, a bluer form of the above 


\section{IRIS}

Iris may be planted almost any time, but preferably not at or just previous to blooming time. Iris should be planted very shallow and on dry, well drained soil, except the Siberian varieties and other fibrous rooted kinds, which are moistureenduring. The effect is better if a group of one kind or color is planted rather than single plants of many colors.

\section{Quantity Rates. Kinds priced at:}

$\begin{array}{rrr}10 \mathrm{c} \text { each are } \$ 0.60 \text { per } 10 \text { and } \$ 4.00 \text { per } 100 \\ 15 \mathrm{c} \text { each are } & .80 \text { per } 10 \text { and } 6.00 \text { per } 100 \\ 20 \mathrm{c} \text { each are } 1.00 \text { per } 10 \text { and } & 8.00 \text { per } 100 \\ 25 \mathrm{c} \text { each are } 1.50 \text { per } 10 \text { and } 12.00 \text { per } 100\end{array}$

S. denotes standards, the upright part of the flower; and F, falls.

DWARF IRIS, 5 to 12 inches high, very early, fine for borders.

Cyanea, 10c: S., rich blue; F., dark satiny purple, 6 inches high.

Schneekuppe, 30c: S. and F., pure white, 6 to 10 inches, very fine.

Excelsa, 20c: S. and F., deep clear yellow, 8 inches.

INTERIMEDIATE IRIS: Intermediate in height and season of blooming.

Helge, 15c: S. and F., lemon yellow with pearl shadings, large.

Ingeborg, 25c: S. and F., very fine large pure white.

Walhalla, 15c: S., light blue; F., velvety violet purple.

Maori King, 25c: S., richest golden yellow; F., velvety maroon.

\section{TALL BEARDED IRIS:}

Afterglow, 60c: S. and F., delicate greyish pink shaded yellow.

Ambassador, \$1.00: S., smoky reddish violet; F., dark velvety maroon.

Archeveque, 40c: S., deep violet purple; F., rich velvety violet.

Blue Jay, 40c: S., elear blue; F., dark blue.

Celeste, 30c: S. and F., elear azure blue.

Dalila, 50c: S., coppery bronze; F., velvety crimson.

Darius, 20c: S., canary yellow; F., lilac margined white.

Dr. Bernice, 20c: S., coppery bronze; F., velvety crimson.

Flavescens, 15c: S. and F., pale sulphur yellow, sweetly scented.

Gypsy Queen, 15c: S., old gold shaded pearl; F., reticulated maroon.

Her Majesty, 30c: S. and F., rose pink.

Hiawatha, 30c: S., pale lavender; F., royal purple.

Honorabilis, 10c: S., golden yellow; F., brownish mahogany.

Johan de Witte, 10c: S., bluish violet; F., deep violet veined white.

Juniata, 25c: S., arching; F., flaring, clear blue throughout.

Kermesiana, 15c: Claret red, marked, medium size, endures moisture.

Kochi, 15c: S. and F., rich blackish purple, very large and fine.

Latendresse, 10c: S. and F., ageratum blue throughout.

Lent A. Williamson, 75c: S., lavender violet; F., royal purple.

Loreley, 20c: S., light yellow; F., blue bordered cream.

Mariposa, \$1.00: S., French gray; F., flaked purple.

Mary Garden, 30c: S., pale yellow flushed lavender; F., creamy dotted.

Mad. Chereau, 10c: S. and F., white, frilled pale blue, tall and late.

Mad. Pacquette, 20c: S. and F., bright rosy claret, ruffled, tall. 


\section{IRIS-Continued}

Midwest, \$1.25: S. and F., rufled, dotted, and blushed rose on a white ground.

Mother of Pearl, \$1.00: S. and F., pale bluish lavender, delicately tinted.

Monsignor, 30c: S., deep violet; F., purplish crimson, veined darker.

Mrs. H. Darwin, 15c: S. and F., pure white with purplish veins.

Nibelungen, 30c: S., fawn; F., violet purple, veined purple.

Nokomis, 30c: S., pale lavender white; F., deep violet blue.

Pallida Delmatica 30c: S. and F., light lavender violet.

Parc de Neuilly, 30c: S. and F., rich plum purple, large.

Perfection, 30c: S., light blue; F., dark violet.

Princess Beatrice, 50c: A selected variety of Pallida Delmatica.

Princess Victoria Louise, 25c: S., sulphur yellow; F., rich plum bordered eream.

Prosper Laugier, 30c: S., light bronze red; F., velvety Bordeaux.

Quaker Lady, 40c: S., smoky lavender; F., ageratum blue and old gold.

Queen Alexandria, 25c: S., fawn overeast lilac; F., lilac.

Queen of the Gypsies, 10c: S., bronze; F., purplish red.

Rheine Nixe, 25c: S., clear white; F., violet blue, edged white.

Shekinah, 75c: S. and F., beautiful soft yellow, tall.

Sherwin Wright, 30c: S. and F., golden yellow.

Silver King, Florentina, 15c: S. and F., white slightly tinted lavender.

Souvenir De Mme. Gandichau, \$2.00: S. and F., brilliant black purple.

Storm Cloud, 30c: S., slaty-grey; F., purplish; very large.

Swatara, 50c: S., lobelia blue suffused yellow; F., violet.

White Knight, 75c: S. and F., pure white, late.

Zua, 75c: S. and F., delicate lavender white, ruffled like fine erepe.

\section{SIBERIAN AND OTHER IRIS:}

Blue King, 15c: Siberian, clear blue with very delicate markings.

Cristata, 40c: Creeping, 3 in., rich blue, for the rockery.

Dichotoma, Vesper Iris, 40c: 2 to $3 \mathrm{ft}$, much branched stems, light lavender flower's in afternoons for four weeks in August or September.

Distinction, 25c: Siberian, rich blue with white veining, $3 \mathrm{ft}$.

Emperor, 50c: Siberian, deep violet-blue, large circular falls.

Geo. Wallace, 30c: Siberian, S., azure blue; F., marked white.

Longipetala Superba, 30c: Dainty levender.

Lord Woolsey, 40c: Very tall, large, deep purple.

Mahogany, 40c: Japanese, dark red.

Orientalis, 15c: Siberian, similar to Blue King, but a little darker.

Orientalis Gigantea, 50c: Ivory white, very tall.

Pseudacorus, 30c: Wild, yellow, for the waterside.

Snow Queen, 15c: Siberian, ivory white with yellowish throat.

True Blue (Fryer's), 30c: A selected blue form of the Siberian Iris. 


\section{OTHER HARDY PERENNIALS}

The measure given is the average height and the dates, the blooming period. Most perennials can be mored well either fall or spring, and many of them through the summer. Prices, unless otherwise given: Field-grown plants, $30 \mathrm{c}$ each, $\$ 2.40$ per dozen, $\$ 15.00$ per $100-3$ or more at dozen rates, and 25 or more at hundred rates.

ACHILLEA, Milfoil or Yarrow

eupatorium, filipendulina, 3 to $4 \mathrm{ft}$., bright yellow, all summer.

millefolium roseum, 18 in., rosy-pink, July till October.

The Pearl, 1 ft., pure white, all summer.

tomentosa, dwarf, 6 in., sulphur yellow, July-September.

AGROSTEMMA, Rose Champion or Mullen Pink-21/2 ft., June-July. Tufts of silvery foliage and bright crimson flowers.

ALLYSSUM saxitile, Basket of Gold-1 ft., bright, jellow, early spring, fine for rockery or borders.

ANTHEMUS, Marguerite-2 ft., large golden yellow flowers, all summer.

ARABIS alpina, Rock Cress-1 ft., early, masses of white flowers, fine for rockery or border.

ARENARIA grandiflora, trailing; snow white; May; a fine rock plant.

ARTEMESIA lactifolia- 1 to $5 \mathrm{ft}$., fragrant small white flowers, August-September. frigida-6 to 18 in., very fine white silk foliage, flowers unimportant.

ASCLEPIAS tuberosa, Butterfly Weed-21/2 ft., July-August, bright orange flowers in umbels.

ASPERULA odorata-6 to 8 in., small white flowers in May. For carpeting shady places.

ASTERS-Abendrothe, 4 ft., deep rose, September.

Elta, 4 ft., double, pale lilac, September.

Japanese Double, 3 to $4 \mathrm{ft}$., pale lavender almost white.

Nova-angliae roseum superbum, 5 to $6 \mathrm{ft}$., near red, September.

sub-coerulea, 12 to 18 in., pale blue with golden center, June.

ASTILBE arendsi, Rose Pearl-2 to 3 ft., June-July, bright pink, likes moisture.

Meta Immink-4 ft., dense spikes of clear pink.

BAPTISIA australis-2 to $3 \mathrm{ft}$, dark blue pea-flowers in June.

BELLIS perennis, Double English Daisy-6 in., crimson to white, May-June.

BLEEDING HEART, 60c: Dicentra spectabilis-1 to $2 \frac{1}{2} \mathrm{ft}$., early, shade-enduring.

BLEEDING HEART, Fern Leaved, 50c: Dicentra eximia-Dwarf, ererblooming, finely cut foliage, splendid for rockery, shade or sun.

BOLTONIA asteroides-Branches 5 to $6 \mathrm{ft}$, September, white aster-like flowers.

CAMPANULA-carpatica, Harebell-Dense mat 8 in., clear blue, June to October. rapunculoides-12 to 18 in., upright racemes of nodding purplishblue flowers mostly in June, but through the summer.

CENTRANTHUS ruber-11/2 ft., June-October, red flowers in heads.

CENTUREA montana-2 ft., July-September, large violet blue flowers in heads.

CERASTIUM biebersteini-9 in., white cottony foliage, white flowers.

tomentosum, snow in summer-Trailing, gray foliage, white flowers.

CHRYSANTHEMUMS-Hardy

Carrie, rich yellow, July-October.

Eva, deep pink, July to October.

Glory of Seven Oaks, 3 ft., golden yellow, July to October.

old Fashioned-Pink, October to Norember.

White, October to Norember.

Yellow, October to Norember.

CLEMATIS recta, 40c-2 to $3 \mathrm{ft}$., June-July, fragrant small white flowers in clusters. 


\section{OTHER HARDY PERENNIALS-Continued}

COLUMBINES, Aquilegia

Chrysantha, 30 in., yellow.

Coerulea, $2 \mathrm{ft}$. , blue shades.

Flabellata, 1 ft., white.

Long Spurred Hybrids, mixed colors.

White, 2 ft., early spring.

COREOPSIS grandiflora, $3 \mathrm{ft}$., deep yellow, all summer.

imbricata, $2 \frac{1}{2} \mathrm{ft}$., large, yellow, all summer.

DAISY-Arctic, $1 \mathrm{ft}$., September-November.

Double White Shasta, 12 to 18 in., all summer.

Giant, 3 to $4 \mathrm{ft}$., July to September.

Shasta, 1 to $2 \mathrm{ft}$., September and October.

DELPHINIUM, Larkspur-Hardy

Belladonna, 3 to $4 \mathrm{ft}$., light blue, all summer.

Bellamosa, 3 to $4 \mathrm{ft}$., dark blue, all summer.

Chinese Blue, $2 \mathrm{ft}$., finely eut foliage, gentian blue, all summer.

Chinese White, $2 \mathrm{ft}$., finely eut foliage, white, all summer.

Gold Medal Hybrids, $4 \mathrm{ft}$. or more, mixed colors, all summer.

DIANTHUS-barbatus, Sweet William, $1 \mathrm{ft}$. mixed colors, in early summer.

deltoides, Maiden Pink, 6 in., small erimson flowers, June-July.

latifolius, $1 \mathrm{ft.}$, brilliant red flowers, all season.

plumarius, Clove Pinks, mixed colors, dwarf, grasslike foliage, early spring.

ECHINOPS ritro, Globe Thistle-2 to 3 ft., metallic blue, July-August.

ENGLISH BUTTERCUP, Ranunculus-Upright, 1 ft., double, bright golden yellow flowers in May and June.

FILIPENDULA ulmaria, Meadowsweet, $2 \mathrm{ft}$., July, ereamy white in feathery plumes FUNKIA, BLUE DAY LIIY, PLANTAIN LILY, HOSTA.

Coerulea, 11/2 ft., July, blue drooping flowers, thrives anywhere.

Subcordata Grandiflora, 40c: 3 ft., August-September, white, fragrant.

GALEGIA officinalis Hartlandi, Goats Rue-3 ft., July and August.

GAILLARDIA, 1 to $2 \mathrm{ft.,}$ all summer, red, yellow, and orange blended, endures drouth.

GOLDEN GLOW, 4 to 6 ft., August, large golden yellow flowers.

GYPSOPHYLLA

paniculata, Baby's Breath-2 to $3 \mathrm{ft}$, fine white flowers in late summer.

repens, trailing, white flowers.

HELIANTHEMUIM vulgare, Sun Rose, 1 ft., mixed colors, July-September.

HELIOPSIS pitcheriana, $4 \mathrm{ft}$., deep yellow, July-August.

scabra zinmaeflora, $2 \frac{1}{2} \mathrm{ft}$., large yellow flowers through season.

HEMEROCALLIS, Yellow Day Lily

flava, Lemon Lily, $21 / 2 \mathrm{ft}$., May and June, elear yellow.

Florham, 40c: 3 to $31 / 2 \mathrm{ft}$., very large, rich yellow, July.

fulva, Tawny Lily, 3 to 5 ft., eoppery orange and erimson, July.

Gold Dust, 2 to $3 \mathrm{ft}$., July, very rich yellow.

Kwanso, 3 to $4 \mathrm{ft}$., double, golden bronze, July.

thunbergii, 2 ft., yellow, July.

HIBISCUS, 4 to $5 \mathrm{ft}$,, clear rose colored, 6 in. flowers, July-September.

HOLLYHOCKS, assorted colors, 4 to $7 \mathrm{ft.,} \mathrm{August} \mathrm{and} \mathrm{September.}$

HYPERICUM calycinum, 1 to $2 \mathrm{ft}$, yellow flowers, July-August.

IBERIS semperviviens, dwarf, white, early spring, splendid for edging or rockery.

INCARVILLEA, Hardy Gloxinia, 11/2 ft., large rose pink flowers, through summer, needs protection. 


\section{OTHER HARDY PERENNIALS-Continued}

LILIUM, Lilies, all blooming sized bulbs.

elegans, 30c: Early, upright, orange blossoms.

regal, 50c: White shaded pink, fragrant.

speciosum magnificum, 50c: Tall, pink with erimson dots.

superbum, Turk's Cap, 30c: Orange, tipped red.

tigrinum flore plena, Double Tiger, 30c: One of the commonest varieties.

LINUM, Hardy Flax, 1 to 2 ft., blue, all summer, very choicest, graceful plant.

MYOSOTIS, Forget-Me-Not, dwarf, blue, early summer, needs shade.

OENOTHERA

speciosa, 2 ft., large, pure white, July-August.

youngii, Sundrops, Evening-Primrose, 2 ft., June-August, bright lemon yellow.

PENSTEMON

barbatus, 3 ft., June to August, bright scarlet.

grandiflora, $2 \mathrm{ft}$., large lilac or lavender blue flowers, June, thrives in sand or dry places only.

PHYSOSTEGIA, False Dragonhead

virginica, 3 to $4 \mathrm{ft}$., August-September, spikes of delicate pink.

virginica alba, a white form of the above, July-August.

virginica vivid, 2 to $3 \mathrm{ft}$, deep pink, September-October.

PLATYCODON, Balloon Flower

grandiflora, $2 \mathrm{ft}$., June to October, large blue or white bell-shaped flowers. Among the finest perennials.

mariesi, 12 to 15 in., otherwise like above, very fine.

PLUMBAGO larpentae, 10 to 12 in., compact, cobalt-blue, from July to freezing.

POPPY-Iceland, 1 to $2 \mathrm{ft}$., mostly yellow.

Oriental, $2 \mathrm{ft}$., large scarlet flowers, centers black, June, transplant in August.

pilosum, 18 in., orange flowers, July-September.

PYRETHRUM, Persian or Painted Daisy, from seed, colors not sure.

Hybridum, 2 to $3 \mathrm{ft}$., pink and white, May to July.

Atrosanguinea, mostly darker shades than the above.

RANUNCULUS repens, ereeping, golden yellow, June.

SALVIA turkestanica, $3 \mathrm{ft}$., large decorative wooly leaves, small white flowers.

SAPONARIA, Soapwort, dwarf, small rosy flowers, in early summer.

SCABIOSA caucasica, Blue Bonnet, $2 \mathrm{ft}$., lavender flowers, all summer.

SEMPERVIVIEN, House Leek, Rosettes of succulent leaves, for dry places.

SOLIDAGO-Golden Wings, $4 \mathrm{ft}$., immense wide panicles of golden yellow, August.

missouriensis, Aster flowered Golden Rod-2 ft., compound panicles of yellow aster-like flowers in August.

STATICE latifolia, Sea Lavender, 1 to $2 \mathrm{ft}$, small purplish blue flowers, broad thick leaves.

STOKES ASTER, 1 to $2 \mathrm{ft.,} \mathrm{large} \mathrm{lavender} \mathrm{blue} \mathrm{flowers,} \mathrm{July} \mathrm{to} \mathrm{October.}$

STONECROP, Sedum or Liveforever

Acre, Golden Moss, creeping green foliage and bright yellow flowers.

Album, 3 in., round, green foliage, small white flowers.

Anglicum, 2 in., forms a bluish green mat.

Coccinea, 6 to 8 in., red flowers.

Ewersi, gray foliage, 2 to 3 in., rosy flowers.

Kamchaticum, 6 in., bright light green, yellow flowers.

Rupestre, 4 to 6 in., reddish stems.

Sieboldi, Japanese, 6 in., bright pink, September.

Spectabile, 1 to $2 \mathrm{ft}$, bright pink, August and September.

Spectabile Brilliant, like above but much darker pink.

Spectabile Variegata, smaller than Spectabile and has variegated foliage. 


\section{OTHER HARDY PERENNIALS-Continued}

THALICTRUM, Meadow Rue or Feathered Columbine

adiantifolium, 40c: 1 to $2 \mathrm{ft}$, yellowish, June and July.

flavum, 3 to $4 \mathrm{ft}$., lemon yellow, fine foliage, July.

glaucum, 40c: 1 to $2 \mathrm{ft}$, pale yellow, July and August.

THYMUS, Thyme, make dense earpets on dry sunny places.

album, sheet of white in June-July.

coccineum, a mass of bright erimson in June-July.

TRADESCANTIA

virginica, Spiderwort, 2 to 3 ft., grassy leaves, blue flowers all summer.

virginica, Rose Colored, a pink form of the above.

TUNICA saxifraga, low tufts small pink flowers, all summer.

VERBASCUM HARKNESS HYBRIDS, 3 to $5 \mathrm{ft}$., July-August, spikes of deep yellow flowers.

VERONICA, Speedwell

amethystina, $1 \mathrm{ft}$. , June-July, spikes of amethyst-blue flowers.

elegans, erect, 12 in., pink.

rupestre, trailing, brilliant blue, June.

spicata, 2 ft., deep blue, June.

teucrium, dwarf, 6 to 12 in., May-June, blue.

True Blue, 18 in., long spikes of blue, July-August.

VINCA MINOR, Trailing Myrtle, an evergreen trailing plant for carpeting ground.

VIOLA HYBRIDA, Tufted Pansies, splendid for borders.

Apricot, apricot shaded yellow.

Haslemere, lilac-pink.

Osborn White, creamy white.

\section{FOREST TREE SEEDLINGS}

\begin{tabular}{|c|c|c|c|}
\hline GREEN ASH & $\begin{array}{l}\text { Size } \\
-18 \text { to } 24 \text { in. } \\
12 \text { to } 18 \text { in. }\end{array}$ & $\begin{array}{r}\text { Per } 100 \\
\$ 3.00 \\
2.25\end{array}$ & $\begin{array}{r}\text { Per } 1,000 \\
\$ 25.00 \\
20.00\end{array}$ \\
\hline LACK LOCUST & $\begin{array}{r}2 \text { to } 3 \mathrm{ft} . \\
18 \text { to } 24 \mathrm{in} . \\
12 \text { to } 18 \mathrm{in} .\end{array}$ & $\begin{array}{l}2.50 \\
2.00 \\
1.50\end{array}$ & $\begin{array}{l}22.00 \\
18.00 \\
12.50\end{array}$ \\
\hline BLACK WALNUT & $\begin{aligned} 12 & \text { to } 18 \mathrm{in} . \\
6 & \text { to } 12 \mathrm{in} .\end{aligned}$ & $\begin{array}{l}6.00 \\
4.00\end{array}$ & $\begin{array}{l}50.00 \\
35.00\end{array}$ \\
\hline $\begin{array}{l}\text { CAROLINA POPLARS, 1-year whips } \\
\text { Rooted Cuttings. }\end{array}$ & $\begin{array}{l}5 \mathrm{ft} . \text { and up } \\
4 \text { to } 5 \mathrm{ft} \text {. } \\
3 \text { to } 4 \mathrm{ft} \text {. } \\
2 \text { to } 3 \mathrm{ft} \text {. }\end{array}$ & $\begin{array}{l}8.00 \\
7.00 \\
6.00 \\
4.50\end{array}$ & $\begin{array}{l}75.00 \\
60.00 \\
50.00 \\
40.00\end{array}$ \\
\hline HARDY CATALPA & $\begin{aligned} 12 & \text { to } 18 \mathrm{in} . \\
6 & \text { to } 12 \mathrm{in.}\end{aligned}$ & $\begin{array}{l}1.50 \\
1.00\end{array}$ & $\begin{array}{r}14.00 \\
8.00\end{array}$ \\
\hline HONEY LOCUST & $\begin{array}{l}18 \text { to } 24 \mathrm{in.} \\
12 \text { to } 18 \mathrm{in.}\end{array}$ & $\begin{array}{l}2.50 \\
2.00\end{array}$ & $\begin{array}{l}22.50 \\
17.50\end{array}$ \\
\hline $\begin{array}{l}\text { PECAN SEEDLINGS } \\
\text { Grown from Iowa seed. Splendid for } \\
\text { growing stocks to graft later. }\end{array}$ & $\begin{array}{l}4 \text { to } 6 \text { in. } \\
6 \text { to } 8 \text { in. }\end{array}$ & $\begin{array}{l}5.00 \\
7.50\end{array}$ & 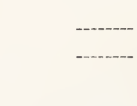 \\
\hline USSIAN MULBERRY & $\begin{array}{r}2 \text { to } 3 \mathrm{ft} . \\
18 \text { to } 24 \mathrm{in} . \\
12 \text { to } 18 \mathrm{in.}\end{array}$ & $\begin{array}{l}3.50 \\
2.50 \\
2.00\end{array}$ & $\begin{array}{l}30.00 \\
22.50 \\
16.00\end{array}$ \\
\hline OFT MAPLE & $\begin{array}{l}18 \text { to } 24 \mathrm{in} . \\
12 \text { to } 18 \mathrm{in.}\end{array}$ & $\begin{array}{l}2.50 \\
2.00\end{array}$ & $\begin{array}{l}22.00 \\
16.00\end{array}$ \\
\hline
\end{tabular}




\section{GRAFTED NUT TREES}

HICKORIES

PECANS

HICCANS

CHESTNUTS

A demand for these trees will greatly exceed the supply for some time because of the limited number of stocks which will be ready to graft, it taking from three to eight years for them to attain sufficient size. The stock ready for sale the spring of 1928 is very limited and a list of kinds a vailable will be sent to those asking for it. Some trees can be supplied of topworked hickories which were grafted about four feet high on shagbark stocks and are now about six feet high. This size has less trouble from bark bursting than smaller trees. Write for arailable kinds.

BLACK WALNUTS. The Thomas walnut is best known and most planted of the grafted rarieties. The tree is hardy, very vigorous growing, productire, and a very young bearer, switches one year old often bearing the following season. The nut is large, fairly thin-shelled, easily cracked, and yields ten pounds or more per bushel of light-colored meats of fine quality.

Ohio is a close rival of the Thomas and by some is considered rather superior to it in certain respects.

Stabler is a native of Maryland and not as hardy as Thomas or Ohio. The nut is of fair size, very thin-shelled, and often not dirided, so the meats can be extracted in one piece. All trees quoted are one-year tops grafted on transplanted stock.

$\begin{array}{cccccc}\text { PRICES- } & 5-6 \mathrm{ft} . & 4-5 \mathrm{ft} . & 3-4 \mathrm{ft} . & 2-3 \mathrm{ft} . & 18-2 \pm \mathrm{in} . \\ \text { Thomas } & \$ 3.00 & \$ 2.50 & \$ 2.25 & \$ 2.00 & \$ 1.50 \\ \text { Ohio } & & & 2.25 & 2.00 & 1.50 \\ \text { Stabler } & & & & 2.00 & 1.00\end{array}$

THE WINKLER HAZLENUT is the best and largest of many kinds we have tried. The nuts are produced freely, are larger than many European Filberts and have the choice quality of the small wild hazlenut. They are uniformly large, sometimes over one inch long. Often the kernels almost burst the shells open and they can be easily pried apart with a light knife. The bush is shapely and grows to about six feet, making a desirable ornamental shrub. The foliage is good and none on the place was more beautifully colored this fall.

$\begin{array}{lrr}\text { Heary bushes } & & \$ 4.00 \mathrm{each} \\ \text { Strong divisions } & 3-4 \mathrm{ft} . & 2.50 \text { 6 } \\ \text { Well rooted divisions } & 2-3 \mathrm{ft} . & 1.0066\end{array}$

The two larger sizes often bear the same year transplanted.

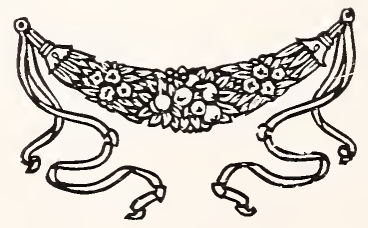


1.
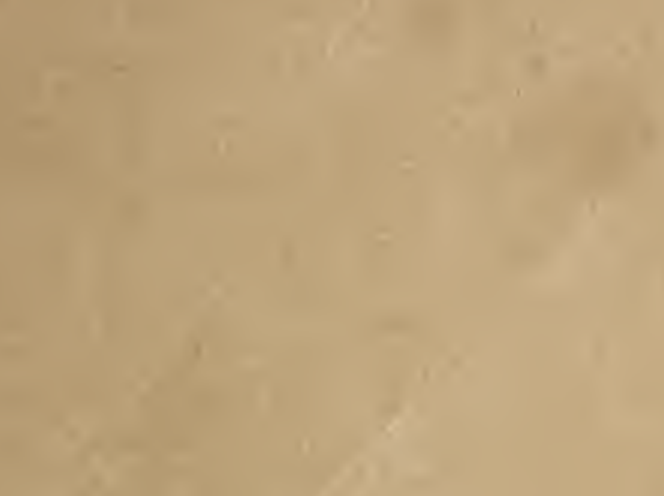

$+\sqrt{2}+1$
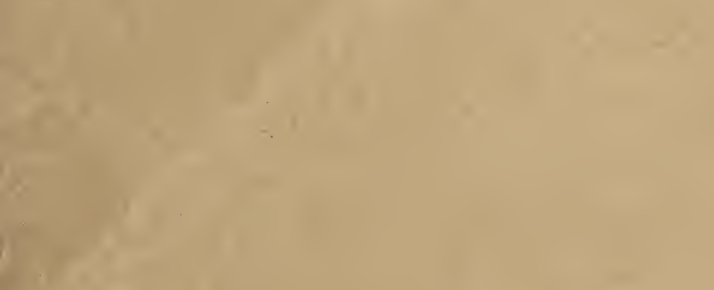

\section{.}

(1) $=1$

4

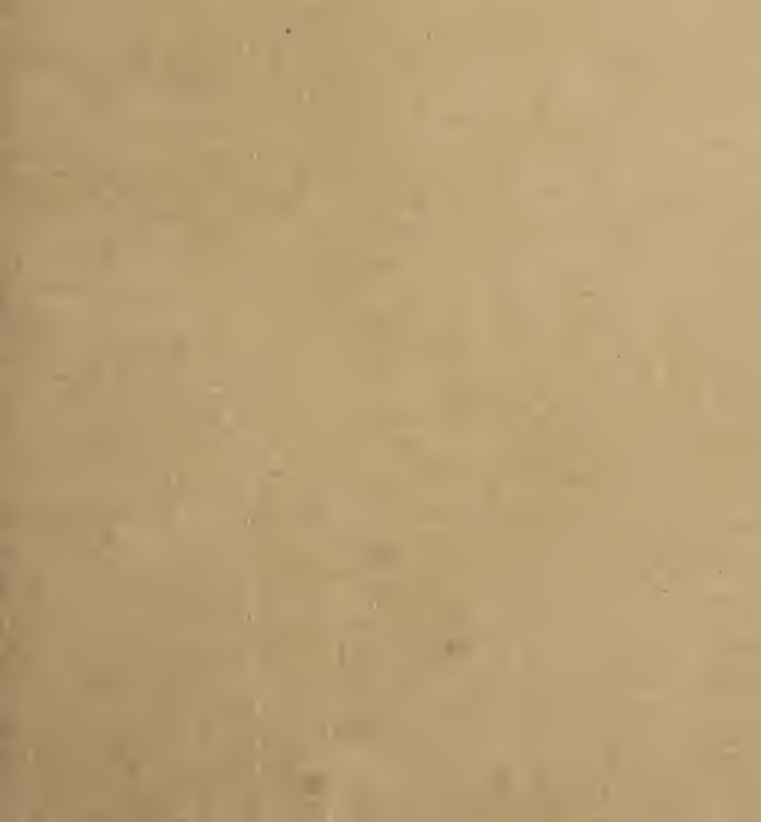


